\title{
Nieznana oprawa dla Jana Łaskiego w Bibliotece Uniwersyteckiej w Poznaniu. Przyczynek do badań nad italianizmem w introligatorstwie polskim XVI wieku ${ }^{1}$
}

\begin{abstract}
Streszczenie. Punktem wyjścia artykułu jest analiza nowo odkrytej oprawy z księgozbioru Jana Łaskiego (1499-1560). Nacisk położono na charakterystyczne składniki italianizującej dekoracji okładzin. Dzieło zostało osadzone na tle renesansowego introligatorstwa włoskiego, w tym głównie dorobku introligatorów skupionych w środowisku weneckim. Osobną uwagę poświęcono superekslibrisowi w formie naśladującej charakterystyczny typ włoskiej tarczy herbowej testa di cavallo. W dalszej części poruszono kwestię miejsca wykonania oprawy oraz jej autora. Z dokonanej analizy porównawczej z italianizującymi oprawami krakowskimi z lat 20. XVI wieku wynika, że jest to dzieło Macieja z Przasnysza, określanego w literaturze jako Mistrz Główek Anielskich. Zaawansowane formy renesansowe dzieł tego introligatora, w tym oprawy z poznańskich zbiorów, przesądzić muszą o uznaniu go za czołowego europejskiego twórcę, błyskawicznie przyswajającego nawet najświeższe tendencje $\mathrm{w}$ introligatorstwie Italii.
\end{abstract}

SŁowA KLuczowe: Jan Łaski, Joannes a Lasco, Maciej z Przasnysza, introligatorstwo renesansowe, italianizm, oprawa książkowa, superekslibris.

Sylwetka historyczna Jana Łaskiego vel Joannesa a Lasco (1499-1560) od dawna budzi zainteresowanie polskich i zagranicznych badaczy. Wpłynęła na to jego aktywna działalność reformatorska w kraju oraz w Anglii, Niemczech i Fryzji Wschodniej, w której okresowo zajmował stanowisko efora tamtejszych Kościołów protestanckich². Owocem jego humanistycznych

${ }^{1}$ Artykuł powstał w ramach badań realizowanych w 2011 roku dzięki stypendium Fundacji Lanckorońskich oraz Stypendium im. Theodora Koernera.

2 H. Kowalska, Łaski Jan, w: Polski stownik biograficzny, t. 18, Wrocław 1973, s. 237-244, tamże wcześniejsza bibliografia. Z nowszych publikacji: H. Kowalska, Działalność reformatorska Jana Łaskiego w Polsce 1556-1560, Warszawa 1999; Jan Łaski 
zainteresowań były bliskie kontakty z Erazmem z Rotterdamu, z którym zetknął się po raz pierwszy w 1524 roku. Krótko po tym Łaski roztoczył nad nim opiekę finansową, przejawiającą się m.in. zakupem na szczególnych warunkach prywatnej biblioteki filozofa. Na mocy umowy z 1525 roku wypłacił on Erazmowi 200 złotych guldenów, stanowiących połowę uzgodnionej wartości księgozbioru, który został w dyspozycji właściciela aż do jego śmierci. $W$ istocie, ponad 400 tomów ze zbioru rotterdamczyka znalazło się w posiadaniu Łaskiego dopiero w 1537 roku, gdy specjalnym transportem sprowadzono je do Krakowa. Oprócz nich Łaski posiadał bliżej nieokreśloną liczbę ksiąg, z których pierwsze nabywał zapewne podczas studiów w Rzymie (1513-1514), Bolonii (1515-1518) i Padwie (1518-1519). Jakkolwiek liczne podróże i tułaczki emigracyjne nie sprzyjały pomnażaniu księgozbioru (wiadomo, że na początku lat 40. XVI wieku - podczas pobytu w Emden - nosił się z zamiarem sprzedaży jego części) ${ }^{3}$, to niewątpliwie do prywatnej kolekcji Łaski włączał księgi przydatne chociażby w działalności teologicznej. W młodzieńczych latach utrzymywał kontakty z krakowskimi księgarzami, a nawet miał na Rusi wysłanników poszukujących zaginionych greckich manuskryptów ${ }^{4}$. Humanistyczny kult książki wyrażał się u niego opatrywaniem kart tytułowych wpisem własnościowym o znamiennej formule "Joannis à Lasco Poloni \& amicorum”. Oprawy jego woluminów odznaczały się zaś wyszukanymi formami dekoracji o wyraźnym pierwiastku renesansowowłoskim. Niewątpliwie było to skutkiem fascynacji kulturą Italii, upowszechniającej się w kręgach północnoeuropejskich humanistów. Przemożny wpływ na gusta szlachcica musiał mieć także jego pobyt w głównych ośrodkach włoskiego introligatorstwa renesansowego z Wenecją na czele. Miasto to odwiedził w 1525 lub na początku 1526 roku, tuż przed powrotem do kraju z Bazylei, po którym nastąpiły jego zamówienia ksiąg o nowatorskiej szacie zewnętrznej. Ewidentny italianizm opraw Łaskiego sprawił, że już w okresie międzywojennym wprzęgnięto je w euro-amerykański dyskurs tegumentologiczny. Przejawia się on głównie eksponowaniem jego ksiąg w katalogach światowych kolekcji i wystaw oraz analizami w kontekście istotnych zjawisk w introligatorstwie europejskim pierwszej połowy XVI wieku ${ }^{5}$.

1499-1560 w pięćsetlecie urodzin, red., wstęp W. Kriegseisen, P. Salwa, Warszawa 2001; H.P. Jürgens, Jan Łaski 1499-1560. Europejczyk doby reformacji, Warszawa 2006.

${ }^{3}$ H. Kowalska, op.cit, s. 239.

${ }^{4}$ Np. L. Hajdukiewicz, Księgozbiór i zainteresowania bibliofilskie Piotra Tomickiego na tle jego działalności kulturalnej, Wrocław 1961, s. 18; H.P. Jürgens, Jan Łaski..., s. 17.

${ }^{5}$ G.D. Hobson, Bindings in Cambridge Libraries, Cambridge 1929, s. 64-65, tabl. nienum.; I. Schunke, Die Einbände der Kirchenbibliothek in Emden, „Archiv für 
Większość zachowanych do dziś woluminów z księgozbioru Łaskiego, w tym słynne erasmiana, znajduje się w Johannes a Lasco Bibliothek w niemieckim Emden. W świetle drukowanych katalogów i innych publikacji obecnie wzbogacają zbiory także Biblioteki Jagiellońskiej ${ }^{6}$, British Library $^{7}$, biblioteki Societe de $l^{\prime}$ Histoire du Protestantisme w Paryżu ${ }^{8}$ oraz Uppsala Universitetsbibliotek ${ }^{9}$. Przed wojną wzmiankowano o jego księgach również w bibliotekach karmelitów we Lwowie i augustianów w Krakowie ${ }^{10}$.

W 2011 roku zidentyfikowano dotychczas nieznany literaturze egzemplarz lascianum $\mathrm{w}$ Bibliotece Uniwersyteckiej w Poznaniu. Jest to klocek druków Erazmiańskich wydanych w Bazylei i Strasburgu ${ }^{11}$. Na niektórych kartach zachowały się zapiski z epoki, trudno byłoby jednak łączyć je ze słynnym filozofem ${ }^{12}$. Najprawdopodobniej zostały naniesione przez Łaskiego, za czym przemawia charakter pisma znany z innych -

Buchbinderei" XXXVI, 1936, s. 71; eadem, Vom Stil der Corvineneinbände, "Gutenberg Jahrbuch" 1944/49, s. 219-220, il. 9; B. Nuska, Polski wptyw na formowanie się czeskiej renesansowej oprawy ksiażkowej, "Ze Skarbca Kultury” 1964, z. 16, s. 57-58, 179-180; H.M. Nixon, Quelques reliures d'un intérêt particulier pour les Polonais dans les bibliothèques anglaises, w: VIIle Congrès International des Bibliophiles, Varsovie, 23-29 juillet 1973, Varsovie 1985, s. 64-67; A. Hobson, Humanists and Bookbinders, Cambridge 1989, s. 158; O. Mazal, Das Erbe der Antike im Schmuck des europäischen Einbandes, "Bibliothek und Wissenschaft" 1996, t. 29, s. 191, 193; H.P. Jürgens, Johannes a Lasco. Ein Leben in Büchern und Briefen. Eine Ausstellung der Johannes a Lasco Bibliothek, Wuppertal 1999, s. 136-141, kat./il. 2.3.1-2.3.3; M.M Foot, The Henry Davis Gift. A Collection of Bookbindings, t. 3: A Catalogue of South-European Bindings, New Castle 2010, s. 491, il. na s. 490 .

${ }^{6}$ Sygn.: BJ Aug 10002 IV, BJ 59033 III, BJ 590156 I.

7 M.M Foot, op.cit.

${ }^{8}$ G.D. Hobson, Bindings..., s. 64.

9 A. Heymowski, Reliures armoriées polonaises de l'époque des Jagiellon et des Vasa dans les collections suédoises, w: VIIle Congrès International des Bibliophiles, Varsovie, 23-29 juillet 1973, Varsovie 1985, s. 154.

${ }^{10}$ G.D. Hobson, Bindings..., s. 64, powołujący się na Kazimierza Piekarskiego.

${ }^{11}$ Sygn. B. UAM: SD 2662. I-2665. I; klocek zawiera (w kolejności oprawienia): Virginis Matris apud Lauretum culte Liturgia [...] Erasmum Roterodamum, Bazylea, oficyna Johanna Frobena 1525; De libero arbitrio $\triangle I A T P I B H$, siuc collatio [...] Erasmi Roterod., Bazylea, oficyna J. Frobena 1524; Parabolae sive similia D. Erasmi Roterodami [...], Strasburg, oficyna Johanna Knoblocha 1523; De immensa dei Misericordia, Des. Erasmi [...], Bazylea, oficyna J. Frobena 1524.

${ }^{12} \mathrm{~W}$ światowych bibliotekach wciąż natrafia się na księgi z prywatnego zbioru Erazma, noszące ślady jego notatek, zob. np. C. Carena, Notizie inedite su Erasmo de Rotterdam in un incunabulo di lirici latini e un suo nuovo rittrato, "La Bibliofilia" CX, 2008, nr III, s. 241-254, il. 1-2. 
wykaligrafowanych na humanistyczną modłę - tomów bibliofila oraz różnorakich tekstów jego autorstwa ${ }^{13}$. Na bocznym obcięciu bloku książkowego zachowały się wyblakłe tytuły oprawionych druków.

Godna szczególnej uwagi jest oprawa woluminu z podwójnie wyciśniętym superekslibrisem Łaskiego (il. 1, 2). Sporządzono ją ze skóry bydlęcej lub owczej o charakterystycznym, żółtawym kolorze, którą powleczono dwie cienkie deseczki bukowe (wymienione $\mathrm{w}$ trakcie $\mathrm{XX}$-wiecznej konserwacji na tekturę). Pierwotnie we wnętrzu oprawy znajdowała się też makulatura drukarska. Przy dłuższych oraz krótszych krawędziach okładzin rozmieszczono tkane wiązania w kolorze zielonym (zachowane szczątkowo). Grzbiet jest spłaszczony, z wydatnymi trzema garbami zwięzów.

Dekorację okładzin wykonano w technice wyciskania (tłoczenia) ślepego i złoconego. Pierwsze z nich obejmuje prawdopodobnie tylko linie oraz ornamenty na grzbiecie, drugie zaś resztę zdobień oraz liternictwo. Drobne fragmenty złoceń dostrzegalne są wciąż w niektórych wyciskach, jednak zawarta w nich domieszka srebra wraz z zabrudzeniami spowodowały niemal całkowite sczernienie dekoracji. Na obu okładzinach ma ona powściągliwą i przejrzystą formę, odznaczającą się zharmonizowaną relacją pomiędzy elementami geometrycznymi, floralnymi i literniczymi a wyeksponowanym w centrum superekslibrisem. Na górnej okładzinie składa się na nią podwójna, linearna rama strychulcowa, której wewnętrzna linia przekształca się na obu osiach w półpierścienie. Ich identyczne rozmiary wskazują na wyciśnięcie ze specjalnego tłoka. Powyżej ramy znajduje się prostokątne pole z trójwierszowym napisem antykwowym "MISSA VIR • MARIE I DE LIBERO ARBI • I SIMILIA ERASMI". U dołu okładziny odpowiada mu wąska listwa z napisem „DE IMESA DEI M[AR]IA". Centrum zwierciadła wyznacza superekslibris z herbem Korab. Po obu jego stronach wyciśnięto inicjały właściciela księgi „, I • L $\cdot$ ". Superekslibris otoczony jest symetrycznie rozmieszczonymi wyciskami tłoków floralnych w formie trójlistka, kwiatonu i tzw. listka aldyńskiego (foglio aldino), skupionych w obrębie półpierścieni.

Niemal analogiczna jest dekoracja dolnej okładziny. Zasadnicza różnica polega na braku w niej górnego pola inskrypcyjnego, zamiast którego u góry i na dole znajdują się wąskie listwy z wyciskami tłoków

${ }^{13}$ Zob. np. H.P. Jürgens, Johannes..., m.in. il./kat. 1.4.5, 1.5.7, 2.1.4, 2.3.1. Notatki rękopiśmienne Łaskiego w Erazmiańskiej edycji Nowego Testamentu z 1522 roku omawia w kontekście humanistycznego zwyczaju opatrywania ksiąg czytelniczymi uwagami M. Engammare, Nowy Testamet Erazma z adnotacjami Jana Łaskiego, w: Jan Łaski 1499-1560 w pięćsetlecie urodzin, red., wstęp W. Kriegseisen, P. Salwa, Warszawa 2001, s. 103-118. 


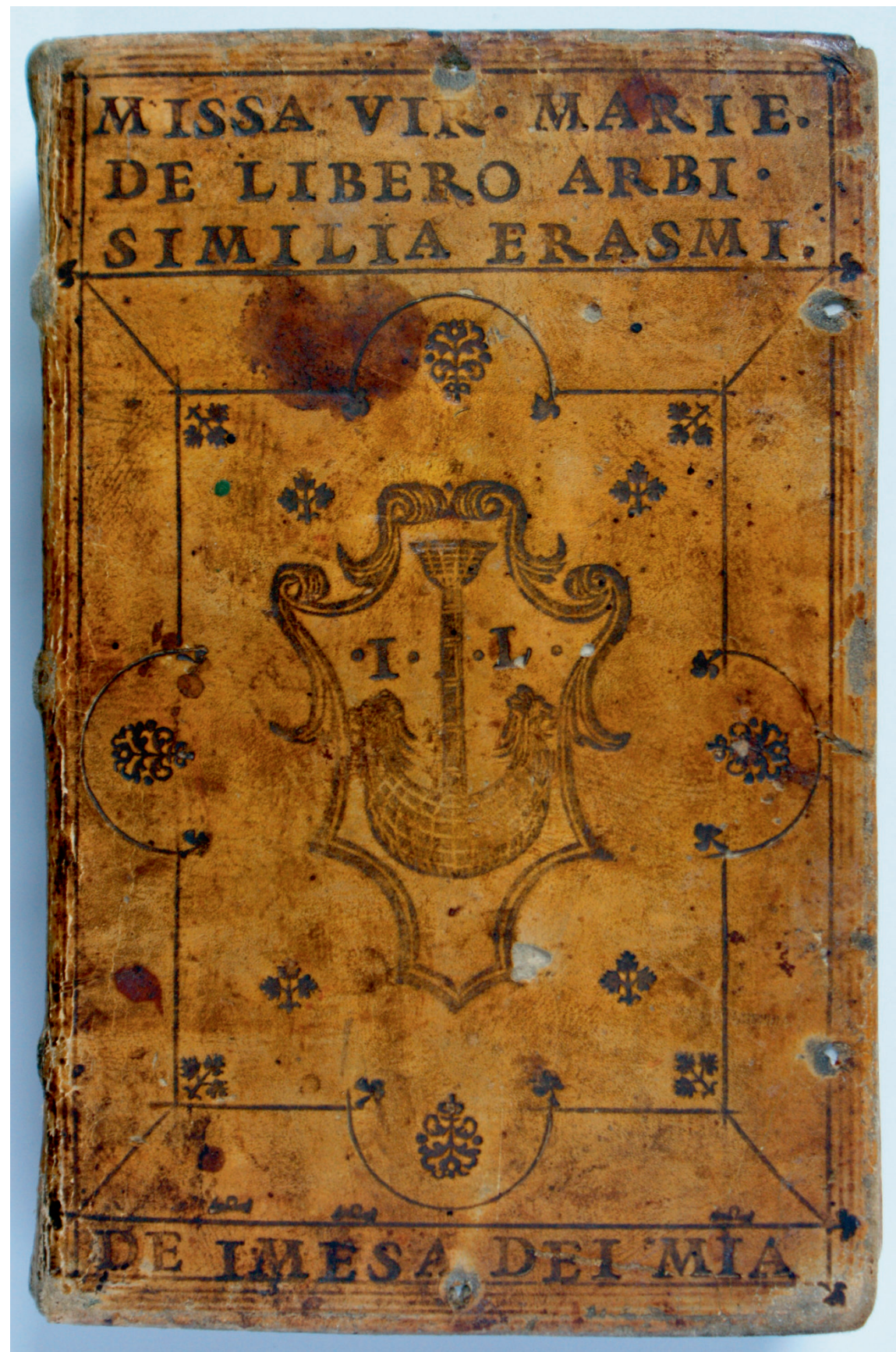

Il. 1. Maciej z Przasnysza (Mistrz Główek Anielskich), oprawa w typie aldyńskim (górna okładzina), Kraków, 1526

Źródło: zbiory Biblioteki Uniwersyteckiej w Poznaniu; fot. Małgorzata Priebe. 


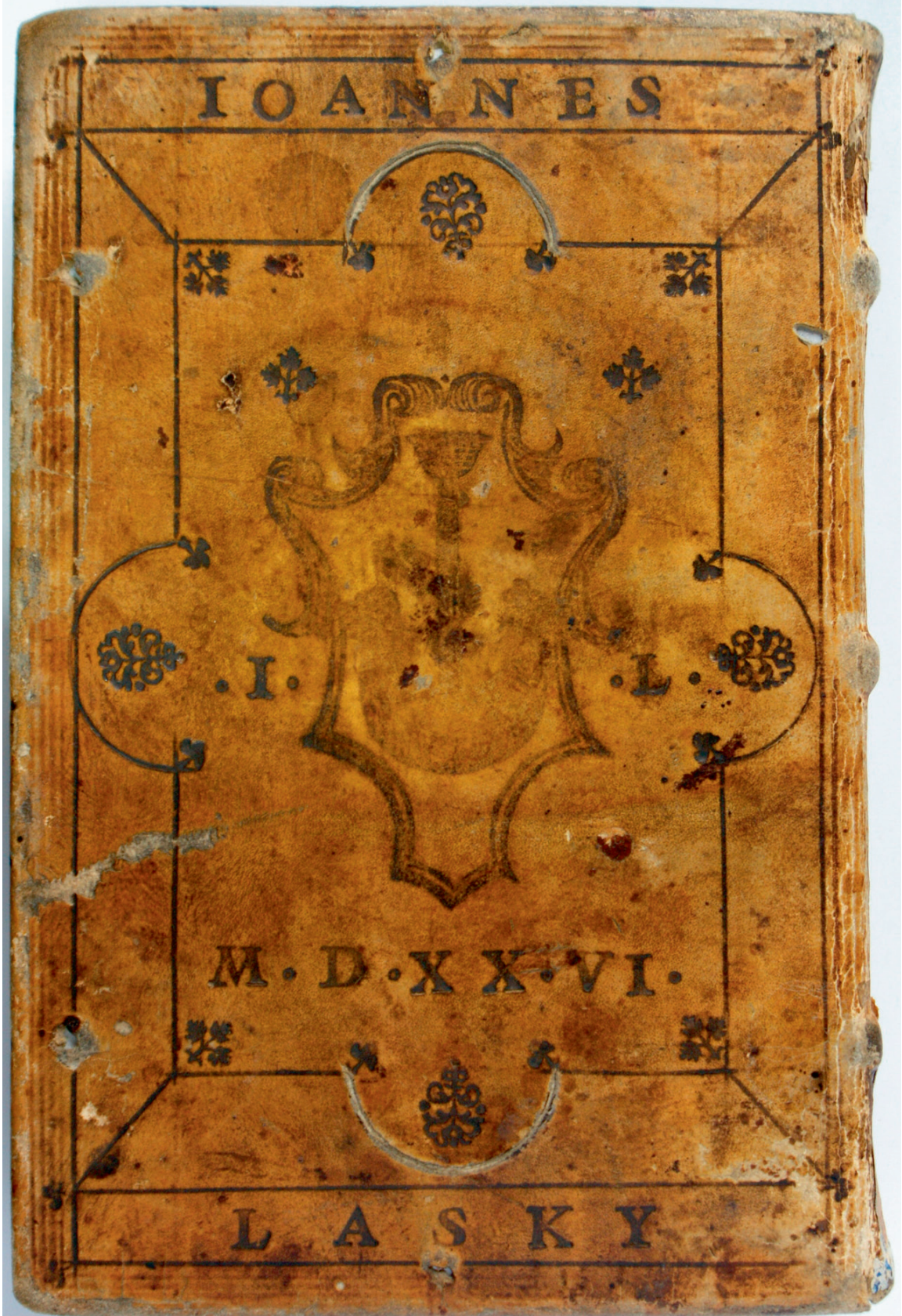

Il. 2. Maciej z Przasnysza (Mistrz Główek Anielskich), oprawa w typie aldyńskim (dolna okładzina), Kraków, 1526

Źródło: zbiory Biblioteki Uniwersyteckiej w Poznaniu; fot. Małgorzata Priebe. 
literniczych „IOANNES | LASKY”. Wskutek tego zabiegu nastąpiło wysmuklenie kompozycji dekoracji, w której superekslibris wyznacza zarówno centrum zwierciadła, jak i optyczne centrum całej okładziny. Wyciski inicjałowe przeniesione zostały z pola tarczy na jej boki, poniżej zaś znalazła się data wykonania oprawy „M • D • XX • VI •”. Dekoracja grzbietu oprawy obejmuje uproszczone wyciski ornamentalne umieszczone w kompartymentach. Dopełniają ją poczwórne linie strychulcowe ujmujące garby zwięzów.

Charakterystyczne cechy formalne dekoracji oprawy - rozumiane jako kompozycja, zestaw wycisków zdobniczych i literniczych, typ tarczy herbowej superekslibrisu, a ponadto wiązania na trzech krawędziach okładzin i spłaszczenie grzbietu - wykazują silne zależności od renesansowego introligatorstwa włoskiego. To zaś skłania do bliższego przyjrzenia się tamtejszym dziełom, stanowiącego punkt wyjścia do próby określenia miejsca powstania i autorstwa lascianum.

Na początku XVI wieku w Wenecji rozpowszechnił się nowy typ oprawy. Wiązał się on z introligatorami wyspecjalizowanymi w oprawianiu kieszonkowych druków oficyny Aldusa Manucjusza, co zresztą usankcjonowało wśród badaczy określenie „oprawy aldyńskie"14. Wyróżnikiem dzieł nowego typu był w pierwszej kolejności materiał: barwiona skóra kozłowa na tekturze, często z tkanymi wiązaniami, wskutek czego oprawiane dzieła zyskiwały na lekkości i poręczności. Ich dekorację oparto na prostych, linearnych ramach, wzbogacanych głównie przez stylizowane motywy floralne oraz rzadziej zoomorficzne i figuralne. Techniką ich nanoszenia na skórę był wycisk złocony, niekiedy uzupełniany lub zastępowany ślepymi wyciskami ram strychulcowych i radełkowych o dekoracji ornamentalnej.

Najprostszą odmianą kompozycyjną dekoracji takich opraw była złocona, prostokątna ramka linearna. U góry lub pośrodku jej zwierciadła umieszczano często antykwowy napis. Gdy znajdował się on pośrodku okładziny, niejednokrotnie otoczony był linearnym pierścieniem, prostokątną ramką bądź floralnym kartuszem. Wewnętrzne i zewnętrzne narożniki zwierciadła ozdabiano pojedynczymi wyciskami skromnych, floralnych tłoków ${ }^{15}$. Inna charakterystyczna odmiana dekoracji oparta

14 Zob. np. O. Mazal, Europäische Einbandkunst aus Mittelalter und Neuzeit, Graz 1970, s. 45-46; G. Bologna, Legature, Milano 1998, s. 38, 99, 101; F. Macchi, L. Macchi, Dizionario illustrato della legatura, Milano 2002, s. 7-8, 478-479.

15 Zob. np. F. Petrucci Nardelli, La legatura italiana, Roma 1989, s. 33, il. na s. 32; A. Hobson, Renaissance Book Collecting. Jean Grolier and Diego Hurtado de Mendoza, Cambridge 1999, il. 45, 50, 59; F. Macchi, L. Macchi, Atlante della legatura italiana. Il Rinascimento (XV-XVI secolo), Milano 2007, il. na s. 176, tabl. 72, 74. 
była na podwójnym, linearnym obramieniu dużego zwierciadła, zazwyczaj z krótkimi, liniowymi łącznikami w narożach. Także w tym wypadku dekorację uzupełniały motywy floralne, takie jak listki aldyńskie oraz rozetki ${ }^{16}$. Z czasem dekoracja nowego typu opraw uległa urozmaiceniu. Przejawiało się to wzbogacaniem formy ram kompozycyjnych, jak również uzupełnianiem wokabularza tłoków charakterystycznymi motywami arabeskowymi (angolari lub mensoli), kwiatonami (ferri aldini), trójlistkami złożonymi z drobnych pierścieni (trifoglia), czy też wyraźnie orientalizującymi motywami plecionkowymi (nodi $)^{17}$.

Wśród wymienionych odmian dekoracji pojawiają się także dzieła formalnie bliskie poznańskiemu cymelium. Linearna ramka wzbogacona jest $\mathrm{w}$ nich na osiach półpierścieniami bądź 3/4-pierścieniami. W zależności od formatu oprawy, ale też inwencji jej wykonawcy, mogły one mieć różne rozmiary ${ }^{18}$. Czubki półpierścieni mogły też stykać się z linią zewnętrznej ramki lub pozostawać w szerokim polu listew. Pierwsze datowane przykłady takich opraw pochodzą z lat 20. XVI wieku i są łączone z Rzymem oraz Wenecją (il. 3) ${ }^{19}$. Należy podkreślić, że na gruncie włoskim owe rozwiązania zdobyły popularność dopiero $\mathrm{w}$ drugiej ćwierci XVI wieku. Wyrazem tego są dzieła weneckich mistrzów, takich jak Andrea di Lorenzo, zwany Mistrzem Mendozy (Mendoza Binder / Meister,

${ }^{16}$ H. Fürstenberg, T. De Marinis, Die italienischen Renaissance-Einbände der Bibliothek Fürstenberg, Hamburg 1966, tabl. na s. 131.

${ }^{17}$ A. Hobson, Renaissance...., il. 46-49, 51-58, 60-62, 81 i inne; F. Macchi, L. Macchi, Atlante..., tabl. 73-74, 77, 79-80.

18 T. De Marinis, La legatura artistica in Italia nei secoli XV e XVI, t. 1, Firenze 1960, tabl. D12/kat. 1225, tabl. XCIII/kat. 545, tabl. CXI/kat. 618, tabl. CXL/kat. 836, tabl. CXC/kat. 1190, tabl. CXCI/kat. 1193; F. Petrucci Nardelli, op.cit., tabl. 4; F. Macchi, L. Macchi, Dizionario..., il. na s. 304, tabl. XIII/a; iidem, Atlante..., tabl. 71, 75.

${ }^{19}$ H. Fürstenberg i T. De Marinis (op.cit., s. 48, tabl. na s. 49) przytaczają oprawę o dekoracji koncepcyjnie bliskiej lascianum, łączoną z dwoma dziełami rzymskimi (T. De Marinis, La legatura..., t. 1, tabl. XCII/kat. 539, tabl. XCIII/kat. 545), z których jedno jest datowane ogólnie na wiek XVI, drugie na 1525 rok). Autorzy przypuszczaja, że ich wzór mógł się wywodzić z określonego typu opraw weneckich; podają też przykłady rzekomych analogii. W rzeczywistości są one jednak odległe od zastosowanego w nich wzoru obramienia. Na tabl. 129 prezentowana jest oprawa druku aldyńskiego z 1522 roku, która z kolei skojarzona jest - bardzo na wyrost - z dwoma dziełami weneckimi zilustrowanymi wcześniej przez De Marinisa (La legatura..., t. 2, tabl. CCCLXXXII/kat. 2160, 2162; w książce Fürstenberga i De Marinisa jest pomyłka w numerze tablicy). W publikacji I. Schunke, Venezianische Renaissanceeinbände. Ihre Entwicklung und ihre Werkstätten (w: Studi di Bibliografia e di Storia in onore di Tammaro De Marinis, t. 4, s.l. 1964, s. 199) rzeczone dzieła weneckie połączone zostały jednak z dorobkiem Mistrza Fuggera, co z kolei zmuszałoby do przesunięcia daty powstania oprawy na lata 40 . XVI wieku. 
Wanderbuchbinder $)^{20}$, Mistrz Fuggera (Fugger Binder / Meister, Granvelle Binder, Apple Binder) działający od lat 40. do 60. XVI wieku' ${ }^{21}$ oraz współczesny mu Mistrz Cycerona (Cicero Binder / Meister) (il. 4) ${ }^{22}$. To zaś czyni z oprawy ze zbiorów poznańskich jeden z najwcześniejszych przykładów zastosowania tego wzoru nawet w wymiarze włoskim (!). Efektowność a zarazem prostota powyższych rozwiązań sprawiła, że były one chętnie podejmowane i rozwijane $w$ dziełach o zróżnicowanym stopniu dekoracyjności. Nie bez znaczenia był fakt formalnego pokrewieństwa najprostszego wariantu dekoracji z określoną kategorią antycznych tablic inskrypcyjnych. Podobny motyw tabula ansata przyjął się zresztą w renesansowym introligatorstwie włoskim ${ }^{23}$. Rzut oka na dorobek tamtejszego introligatorstwa drugiej ćwierci XVI wieku dowodzi też rozpowszechnienia się omawianego wzorca w Bolonii, Rzymie i Florencji ${ }^{24}$. Jego warianty wzbogacone starannie zakomponowanymi motywami floralnymi zdobią również oprawy wykonane dla słynnego bibliofila Jeana Groliera, co wpłynęło z czasem na repertuar dekoracji stosowanych przez introligatorów francuskich ${ }^{25}$. Przynajmniej od początku lat 40. XVI wieku dekoracja tego typu zdobyła popularność także w Polsce $^{26}$.

${ }^{20}$ Ilse Schunke (Venezianische..., s. 198-200) identyfikuje z nim nieatrybuowaną oprawę z dzieła De Marinisa (La legatura..., t. 2, tabl. CCCXXII/kat. 1704); A. Hobson, Renaissance..., il. frontyspisowa, 42, 83; P. Culot, Bibliotheca Wittockiana, Brussels 1996, il. na s. 22; S. Karpp-Jacottet, Einbände venezianischer Buchbinder des 16. Jahrhunderts in den Sondersammlungen der Universitätsbibliothek Leipzig, "Einband Forschung” 2007, z. 20, s. 36, il. nienum.

${ }^{21}$ Np. I. Schunke, Venezianische..., s. 200 (wg il. w: T. De Marinis, La legatura..., t. 2, tabl. CCCCIV/2369), tabl. XVIII; P. Culot, op.cit., il. na s. 22; F. Macchi, L. Macchi, Dizionario..., il. na s. 478-479; iidem, Atlante..., tabl. 81.

${ }^{22}$ I. Schunke, Venezianische..., s. 200 (wg il. w: T. De Marinis, La legatura..., t. 2, tabl. CCCCV/2403); A. Hobson, Renaissance..., il. 73.

23 A. Hobson, Humanists..., s. 162-163; zob. też: http://62.123.203.74/bibliotecamai/cataloghi_inventari/legature_storiche/cassaforte/cassaforte_4_0001.html [dostęp: 12.12.2011].

24 T. De Marinis, La legatura..., t. 1, tabl. D12/kat. 1225, XCIII/545, CXI/618, CXL/836, CXC/1190, CXCI/1193; ibidem, t. 2, tabl. CCXXXI/kat. 1348; H. Fürstenberg, T. De Marinis, op.cit., tabl. na s. 103; A. Hobson, L. Quaquarelli, Legature bolognesi del Rinascimento, Bologna 1998, s. 64, il. 12 (wariant dekoracyjny także z półkolistymi wklęśnięciami w narożach ramy).

25 The British Museum. Bookbindings from the Library of Jean Grolier. A loan exhibition 23 september-31 october 1965, London 1965, il. 28, 29

${ }^{26}$ A. Wagner, Oprawy ksiag Andrzeja Opalińskiego, w: Księgozbiór wielkopolskiego magnata. Andrzej Opaliński (1540-1593), red. A. Wagner, Poznań 2011, s. 150-153. 


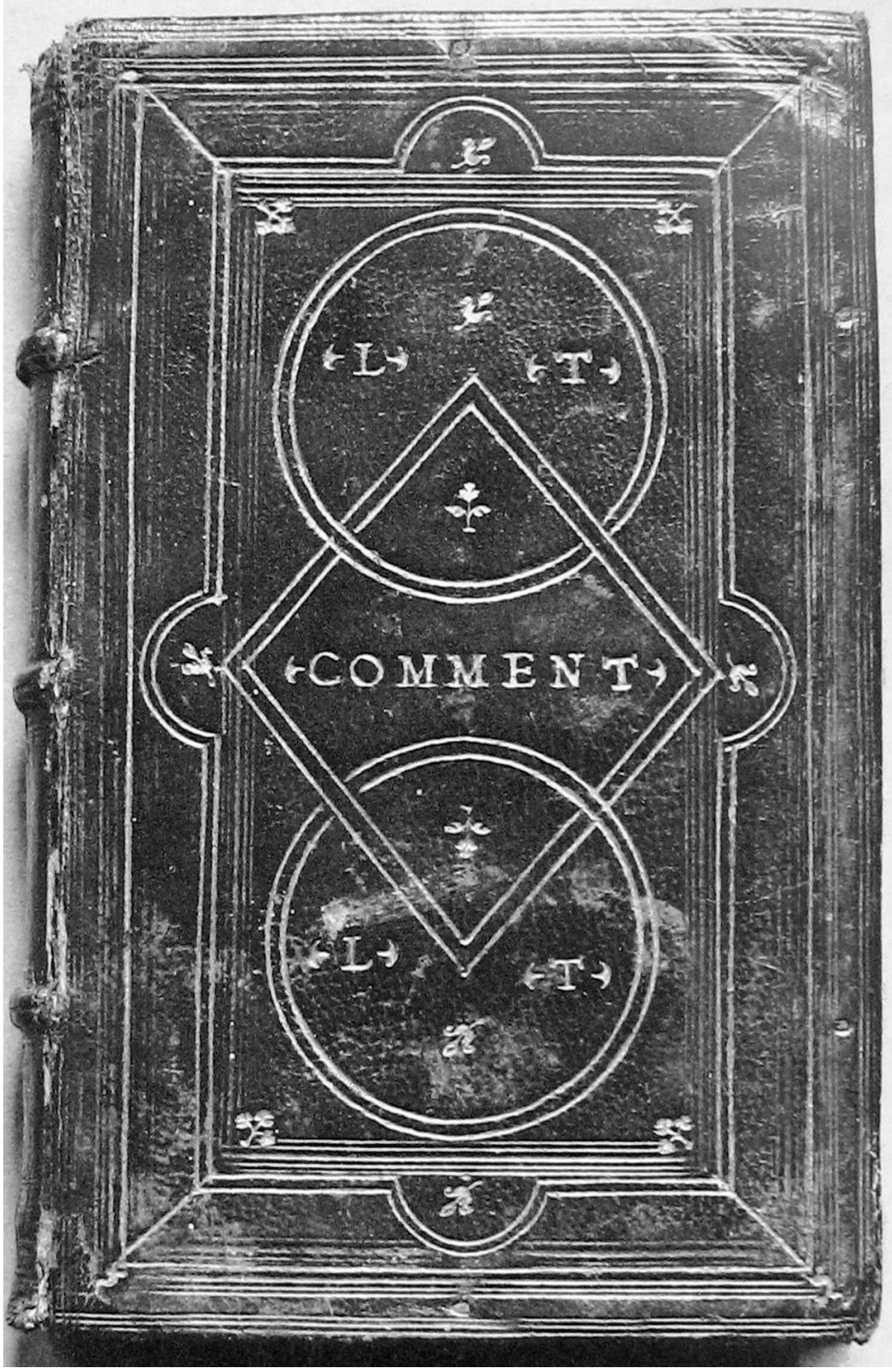

Il. 3. Introligator anonimowy, oprawa w typie aldyńskim (górna okładzina), Rzym? Wenecja?, lata 20. XVI wieku

Źródło: H. Fürstenberg, T. De Marinis, Die italienischen Renaissance-Einbände der Bibliothek Fürstenberg, Hamburg 1966. 


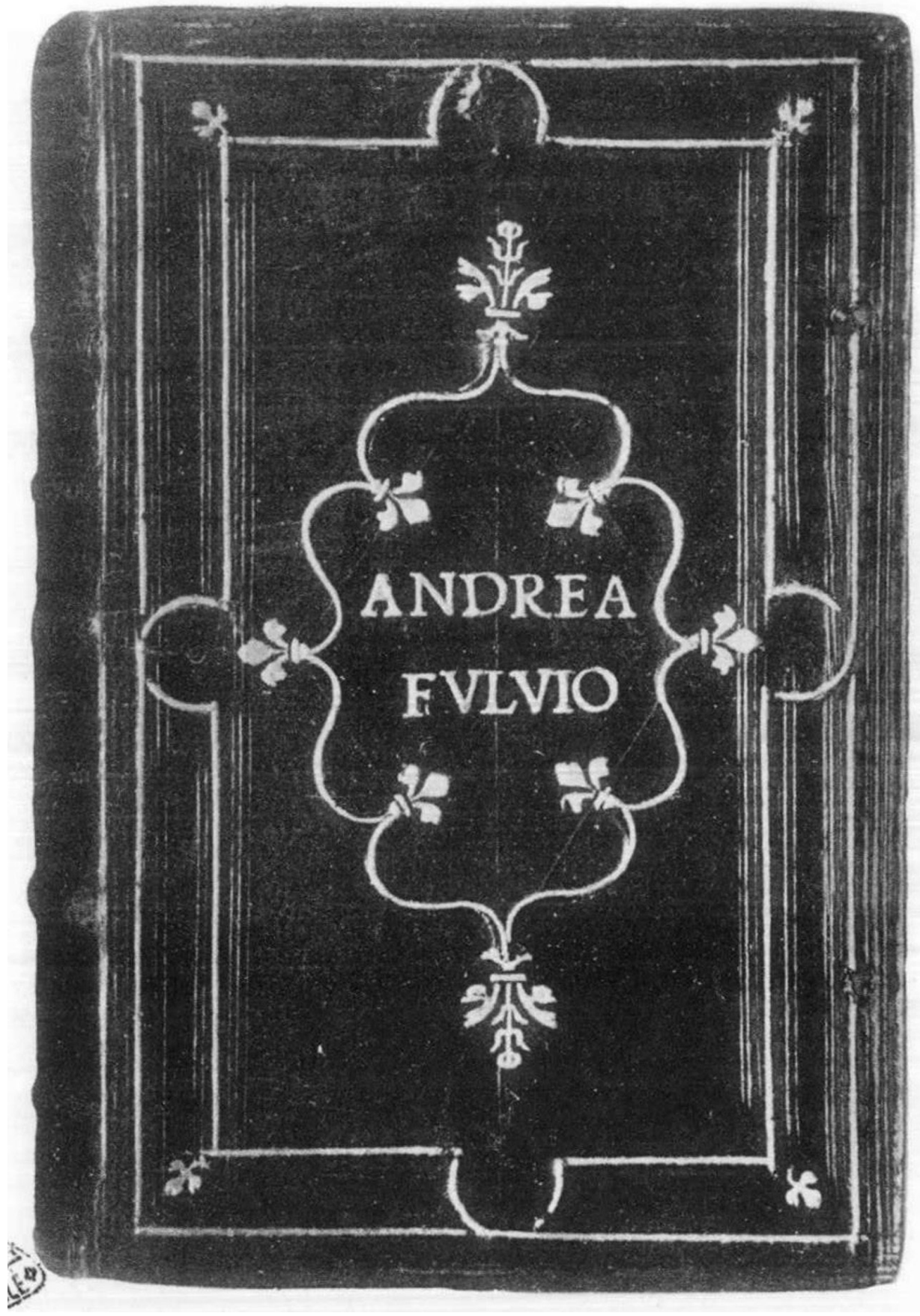

Il. 4. Mistrz Cycerona, oprawa w typie aldyńskim, Wenecja, po 1543 roku Źródło: T. De Marinis, La legatura artistica in Italia nei secoli XV e XVI, t. 1, Firenze 1960. 
Osobnej uwagi wymaga zamieszczony na obu okładzinach superekslibris, którego forma jest specyficznie renesansowowłoska. Tarcze herbowe o wydłużonym kształcie oraz wciętych pobocznicach i szpicu pojawiły się $\mathrm{w}$ heraldyce Italii $\mathrm{w} X \mathrm{X}$ wieku. Ich geneza wiąże się $\mathrm{z}$ elementem zbroi nakładanym na głowy wierzchowców i ozdabianym wizerunkiem herbu, skąd zresztą wywodzi się włoska nazwa tarcz - testa di cavallo (głowa konia) ${ }^{27}$. W toku XV stulecia przeniknęły one do rozmaitych dziedzin sztuk plastycznych i rzemiosła artystycznego w Italii. Istotny był fakt ich stosowania w dekoracji iluminatorskiej jako tzw. protoekslibrisy (ekslibrisy malowane). Lokowano go zwykle pośrodku dolnego marginesu karty, gdzie otaczany był antykizującym wieńcem i wstęgami oraz dekoracją ornamentalną ${ }^{28}$. Formuła ta przeniknęła do iluminatorskiej dekoracji inkunabułów, a także do drzeworytniczych listew ornamentalnych w paleotypach i wczesnych drukach XVI-wiecznych (il. 5) ${ }^{29}$. Często w obrębie dolnej, poziomej listwy znajduje się motyw tarczy z pustym polem przeznaczonym na ręcznie namalowane lub narysowane godło właściciela druku (il. 6). Omawiany typ tarczy był też używany w superekslibrisach ${ }^{30}$. Mimo wyparcia testa di cavallo w ciagu XVI wieku przez manierystyczne i barokowe kartusze herbowe, tarcza ta przetrwała we włoskiej heraldyce właściwie do czasów współczesnych, czego dowodzą niektóre herby papieskie ${ }^{31}$.

Na włoskie pierwowzory naprowadza też skromny zasób tłoków użytych do dekoracji poznańskiej oprawy. Odnosi się to zwłaszcza do

27 P. Guelfi Camajani, Dizionario araldico, Bologna 1940, s. 482-483; G. di Crollalanza, Enciclopedia araldico-cavalleresca. Prontuario nobiliare, Bologna 1964, s. 581; G. Oswald, Lexikon der Heraldik, Leipzig 1984, s. 335; G. Santi-Mazzini, Araldica. Storia, linguaggio, simboli e significati dei blasoni e delle armi, Milano 2003, s. 53.

${ }^{28}$ Zob. np. M. Salmi, La miniatura italiana, Milano 1956, tabl. XLVII, LI/b, LXX/b; I. Berkovits, Corvinen Bilderhandschriften aus der Bibliothek des Königs Matthias Corvinus, Budapest 1963, tabl. I-III, IX, XXXVI, XLV; C. de Hammel, Manoscritti Miniati, Milano 1987, il. 241b, 242.

${ }^{29}$ Zob. np. M. Salmi, op.cit., il. 81; G.M. Canova, La miniatura in Veneto, w: La miniatura in Italia, II, Dal tardogotico al manierismo, red. A. Putaturo, D. Murano, A. Perriccioli Saggese, Napoli 2009, il. 460, 464-465, 473 (tamże tarcza w trzech miejscach całostronicowej kompozycji trompe o'eil); T. De Marinis, Raccolta degli antichi libri veneziani figurati, Verona 1941, tabl. XXV, XLI, LI, LIV, LIX i inne.

${ }^{30}$ Zob. np. T. De Marinis, La legatura..., t. 1, tabl. XLVIII/266, LXXIV/426, LXXVII/925, CLIV/914; F. Macchi, L. Macchi, Dizionario..., il. na s. 307; iidem, Atlante..., s. 70-72, tabl. 22/b (nietypowy przykład herbu namalowanego na dłuższym obcięciu kart), s. 112 , tabl. 39 .

${ }^{31}$ B.B. Heim, Heraldry in the catholic church. Its origin, customs and laws, Gerrards Cross 1981, il. na s. 28-29, 138, tabl. I, VIII i inne. 


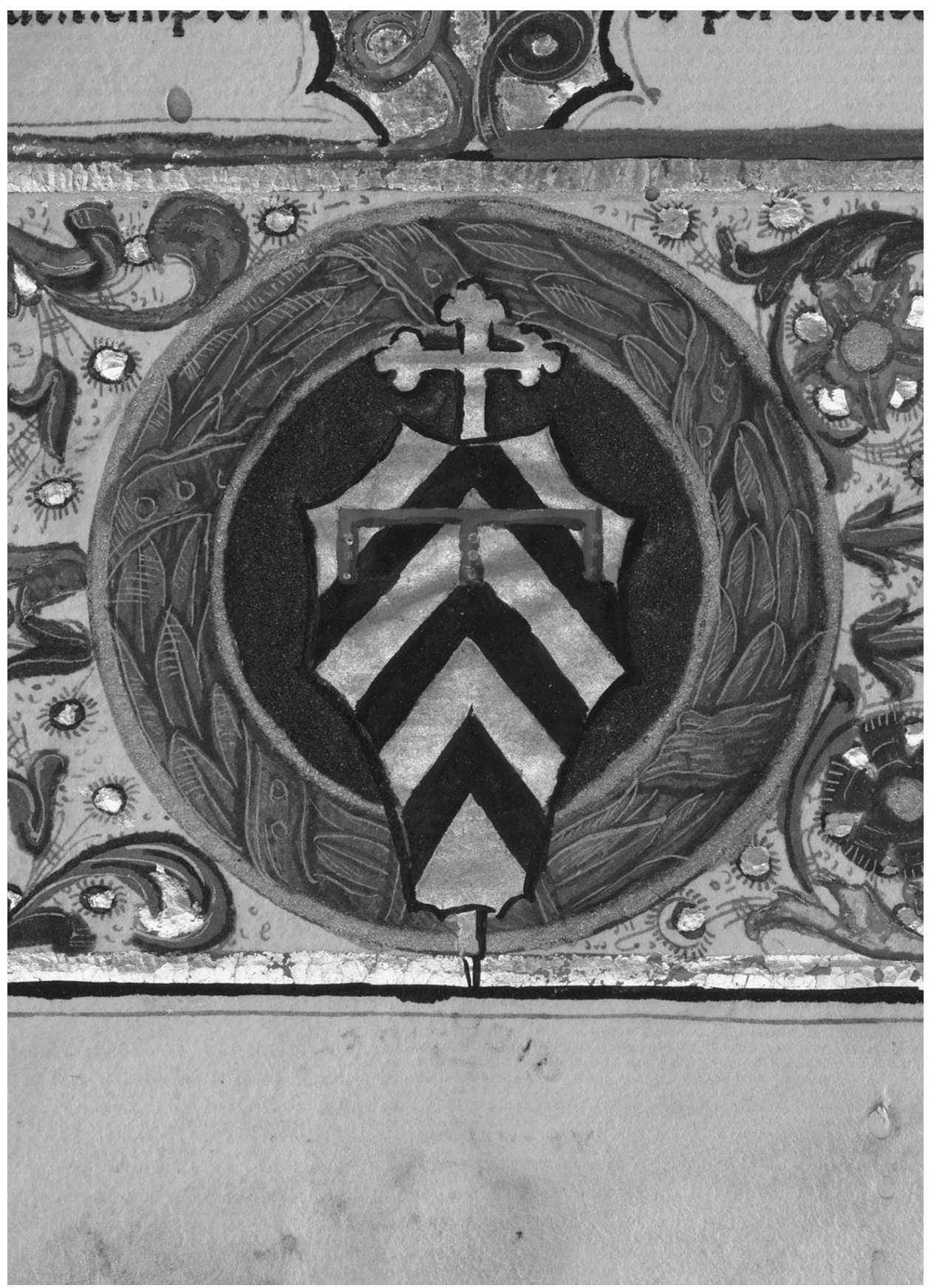

Il. 5. Iluminator anonimowy, ekslibris malowany (protoekslibris) Eustachego de Lévis, Ferrara?, około 1480 Źródło: zbiory Biblioteki Jagiellońskiej; fot. @ C Biblioteka Jagiellońska. 


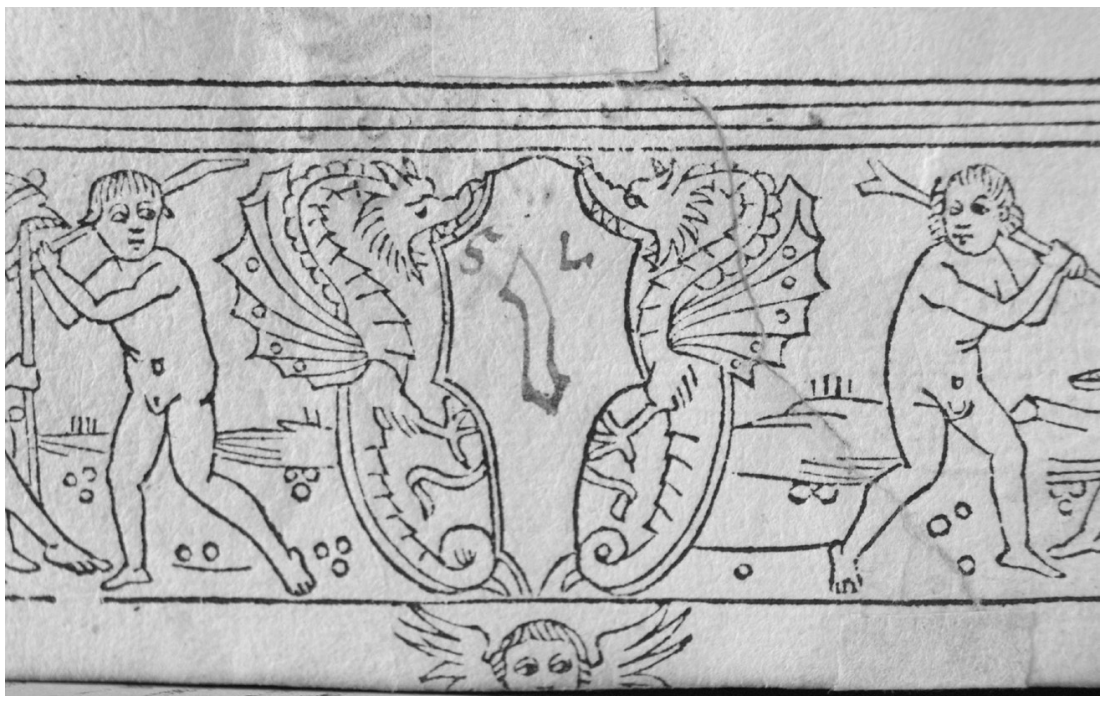

Il. 6. Herb Drużyna i inicjały „S[ebastian (lub) Stanisław] L[ubomirski]” wrysowane w drzeworytniczą tarczę herbową na karcie włoskiego inkunabułu, pierwsza połowa XVI wieku

Źródło: zbiory Biblioteki Seminarium Duchownego we Włocławku; fot. Arkadiusz Wagner.

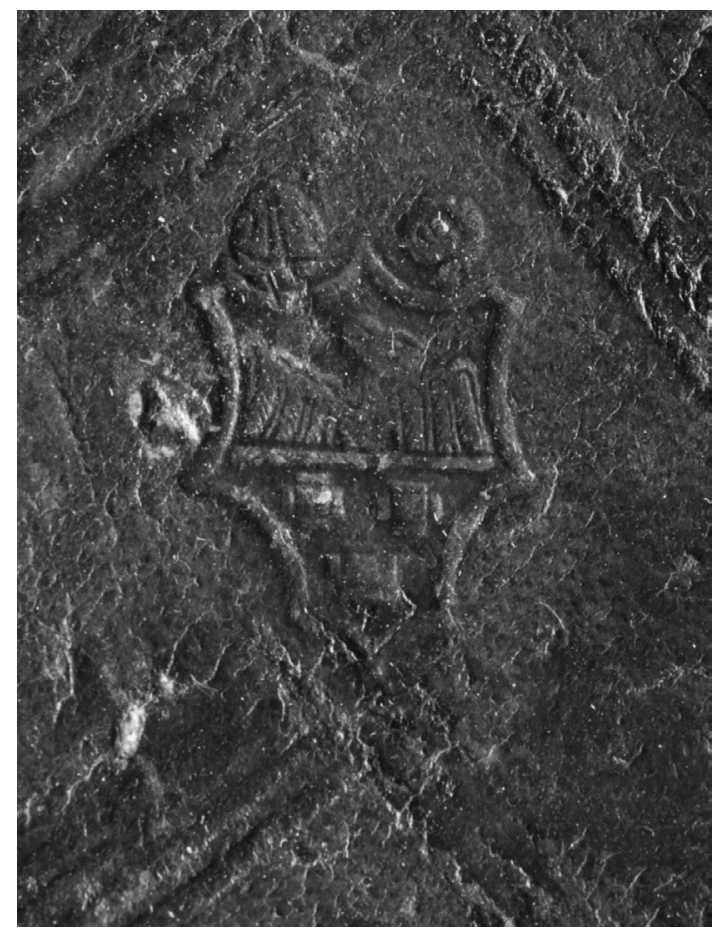

Il. 7. Rytownik (złotnik) anonimowy, superekslibris $\mathrm{z}$ herbem Sulima prawdopodobnie bpa Erazma Ciołka na oprawie krakowskiej z początku XVI wieku

Źródło: zbiory Fundacji XX Czartoryskich $\mathrm{w}$ depozycie $\mathrm{w}$ Muzeum Narodowym w Krakowie; fot. (c) Fundacja XX Czartoryskich. 
motywu małego listka umiejscowionego na styku prostych linii ramy i jej wybrzuszeń, będącego formalnie uproszczonym listkiem aldyńskim. Motyw ten był powszechnie stosowany w przeróżnych wariantach we włoskim introligatorstwie, jak i drukarstwie XVI wieku. Należy również wspomnieć o formie i rozmieszczeniu wiązań oprawy oraz kształcie jej grzbietu. Jakkolwiek bowiem wiązania okładzin skórzanymi rzemykami były znane już $\mathrm{w}$ średniowieczu, to takowe $\mathrm{z}$ barwionych pasków tkaniny rozpowszechniły się dopiero $\mathrm{w}$ renesansowym introligatorstwie włoskim. Przyczyniły się do tego ich taniość i lekkość względem stosowanych na północ od Alp zapięć metalowych uzupełnianych okuciami. To zaś odpowiadało weneckiej koncepcji relatywnie taniej i poręcznej oprawy kieszonkowych druków. Godne pokreślenia jest też rozmieszczenie wiązań zarówno na dłuższych, jak i na krótszych krawędziach okładzin. Znamionuje ono bowiem włoską tradycję introligatorską już od średniowiecza, z tym że zamiast wiązań stosowano wówczas zapięcia metalowe na skórzanych paskach ${ }^{32}$. W końcu warto napomknąć o spłaszczeniu grzbietu z jednoczesnym uwydatnieniem garbów zwięzów, co stanowiło przynajmniej od XV wieku wyróżnik struktury opraw włoskich.

Czy zatem, mając na uwadze kilkuaspektowy italianizm dekoracji i struktury opisywanego dzieła, należałoby uznać go za wytwór introligatorstwa włoskiego? Pytanie zdaje się tym zasadniejsze, że wykonawstwo opraw w renesansowych Włoszech dla polskiej szlachty było zjawiskiem potwierdzonym zachowanymi obiektami ${ }^{33}$. Dokładny ogląd oraz analiza porównawcza z innymi oprawami dla Jana Łaskiego przeczą jednak takiemu domniemaniu. Zarazem wskazują na warsztat krakowski specjalizujący się w produkcji opraw italico modo. Wpływają na to także inne przesłanki, jak zastosowanie deseczek bukowych zamiast tektury jako podłoża okładzin skórzanych, co świadczy o przywiązaniu introligatora (lub/i jego zleceniodawcy) do lokalnej praktyki wzmacniania opraw solidnym, drewnianym tworzywem. $W$ rzeczonym dziele nastąpiło to

32 Popularność opraw z tkanymi wiązaniami, zarówno na jednej, jak i na trzech parach boków okładzin, potwierdzają dzieła renesansowego malarstwa portretowego w Italii, np. Portret młodego mężczyzny z ksiażka Giorgiona, Portret Andrea Odoniego Lorenza Lotto, Portret kobiety Sebastiana del Piombo, portrety Ugolino Martelli oraz Laura Battiferri Bronzina, Portret Jacopo Strada Tycjana i wiele innych (zob. np. N. Macola, Progetto iconografico, w: R. de Bury, Philobiblon. Le passione per i libri, Torino 2006, tabl. 3, 5, 9, 11-12 i inne.

${ }^{33}$ Zob. np. K. Piekarski, Włoska oprawa dla Andrzeja Czarnkowskiego, "Silva Rerum” 1925, nr 5, s. 76-77, tabl. nienum.; Ex Bibliotheca Regia Berolinensi. Schöne und seltene Bücher aus der Abteilung Historische Drucke, Wiesbaden 2000, s. 188, tabl. nienum. 
wszakże w osobliwy sposób, deseczki bowiem są nadzwyczaj cienkie i pozbawione fazowania, co po obłożeniu skórą musiało dobrze imitować sprasowaną tekturę. O jego krakowskim wykonawstwie zdaje się też przesądzać drukarska makulatura, która pochodzi z zasobu typograficznego Hieronima Wietora ${ }^{34}$. To zaś wyraźnie wskazuje nie tylko na krakowską lokalizację warsztatu introligatora, ale też na jego współpracę z oficyną słynnego impresora.

Lata, w których powstało omawiane dzieło, wespół z pozostałymi znanymi dziś oprawami dla Łaskiego, przypadają na okres bujnego rozwoju krakowskiego introligatorstwa. Determinowany był on głównie stołecznym statusem miasta, co powodowało wzmożone zamówienia od urzędów i kancelarii, hierarchów świeckich i kościelnych oraz powiększającego się kręgu szlachty i mieszczaństwa. Związane z Akademią Krakowską środowisko uczonych przyczyniało się co najmniej od pierwszej połowy XV wieku do stałego napływu do stolicy Królestwa rękopisów i druków włoskich ${ }^{35}$. Te zaś prowadziły do stopniowego wyparcia gotyku przez estetykę renesansową $\mathrm{w}$ iluminatorstwie, typografii i grafice książkowej, jak też introligatorstwie. Dynamika życia kulturalnego w Krakowie dostrzeżona została po drugiej stronie Alp, w wyniku czego sam Aldus Manucjusz założył tu agendę swej oficyny ${ }^{36}$, dodatkowo słał liczne woluminy na specjalne zamówienie ${ }^{37}$. Zapewne część spośród aldynów sprzedawanych w Krakowie zaopatrzona była w oryginalne, weneckie oprawy, które stanowiły niewątpliwy wzorzec dla tutejszych bibliofilów i ich introligatorów. W końcu, na gruncie szerszych zjawisk

${ }^{34}$ Według informacji uzyskanych od Zygmunta Poznańskiego z Biblioteki Uniwersyteckiej w Poznaniu na podstawie badań Henryka Bułhaka. Warto nadmienić, że o introligatorskiej makulaturze polskiego druku z 1525 roku wydobytej z oprawy lascianum w Queens' College w Cambridge donosił G.D. Hobson (Bindings..., s. 65).

35 Zob. np. A. Lewicka-Kamińska, Renesansowy księgozbiór Mikołaja Czepla w Bibliotece Jagiellońskiej, Wrocław 1956, s. 18-29; J. Ptaśnik, Kultura włoska wieków średnich w Polsce, Warszawa 1959, s. 301-303; L. Hajdukiewicz, op.cit., s. 21, 35-41; W. Szelińska, Biblioteki profesorów Uniwersytetu Krakowskiego w XV i początkach XVI wieku, Wrocław 1966, s. 44-260, 286-296, 305 i inne; L. Jarzębowski, Biblioteka Mikołaja Kopernika, Torun 1971, s. 17-26; J. Domański, Poczatki humanizmu, w: Dzieje filozofii średniowiecznej w Polsce, t. 9, Wrocław 1982, s. 71-79; E. Potkowski, Książka rękopiśmienna w kulturze Polski średniowiecznej, Warszawa 1984, s. 128, 130, 185-191 i inne; L. Szczucki, Humanizm włoski i kultura polska, „Kultura i Społeczeństwo” R. XLI, 1997, nr 1, s. 37-40.

${ }^{36}$ A. Hobson, Humanists..., s. 158.

37 D. Quirini-Popławska, Działalność Włochów w Polsce w 1. połowie XVI wieku na dworze królewskim, w dyplomacji i hierarchii kościelnej, Wrocław 1973, s. 33. 
kulturalno-artystycznych, ogromną rolę w popularyzacji renesansowego stylu w sztuce odegrał król Zygmunt Stary. Napływający z Zygmuntowskiej inicjatywy od 1505 roku włoscy rzeźbiarze, muratorzy i architekci implantowali w gotyckiej tkance Wawelu i miasta pierwszorzędne dzieła, które stanowiły inspirację dla społecznej elity i otwierały ją na stylowe nowinki $\mathrm{z}$ Italiii ${ }^{38}$. Zapewne niebagatelne znaczenie $\mathrm{w}$ popularyzacji wzorców włoskich opraw książkowych mieli też dworzanie królowej Bony, rekrutujący się spośród 287 osób, które przybyły z nią w orszaku ślubnym. Reprezentująca to środowisko szlachta oraz rozmaici urzędnicy, nauczyciele i wychowawcy królewscy, w końcu lekarze i aptekarze musieli posiadać przynajmniej podręczne księgozbiory przywiezione z ojczyzny ${ }^{39}$.

Wymienione wyżej zjawiska wpłynęły na wcześnie i dynamicznie rozwijający się nurt włoski w lokalnym introligatorstwie ${ }^{40}$. Twórca opraw dla Łaskiego wpisywał się w niego doskonale, czego dowodzą wykonane w jego pracowni dzieła dla najbardziej wymagających i humanistycznie zorientowanych bibliofilów, takich jak bp Piotr Tomicki, Piotr Wedelicjusz z Obornik oraz Jan Łaski ${ }^{41}$. W literaturze tematu określa się go jako

${ }^{38}$ Zob. np. H. i S. Kozakiewiczowie, Renesans w Polsce, Warszawa 1976, s. 9-16, 25-74 i inne; A. Małkiewicz, Die Einstellung der letzten polnischen Jagiellonen zur Kunst, w: Die Jagiellonen. Kunst und Kultur einer europäischen Dynastie an der Wende zur Neuzeit, red. D. Popp, R. Suckale, Nürnberg 2002, s. 49-58; M. Zlat, Sztuka polska. Renesans i manieryzm, Warszawa 2010, s. 12-71 i inne; B. Krasnowolski, Moda włoska i norymberska wśród elity krakowskiej XV-XVI wieku, w: Elita władzy miasta Krakowa i jej zwiazki z miastami Europy w średniowieczu i epoce nowożytnej (do połowy XVII wieku), red. Z. Noga, Kraków 2011, s. 291-302.

39 Reprezentantów wymienionych grup zawodowych na dworze Bony scharakteryzowała D. Quirini-Popławska, op.cit., s. 10-19, 23-45 i inne.

${ }^{40}$ K. Piekarski, Ksiażka w Polsce w XV i XVI wieku, w: Kultura staropolska, Kraków 1932, s. 364-365; Sztuka w Krakowie w latach 1350-1550. Wystawa urządzona w sześćsetletnia rocznicę założenia Uniwersytetu Jagiellońskiego, Muzeum Narodowe w Krakowie, 1964, Kraków 1964, s. 48-49; B. Nuska, op.cit., s. 146-160, 179-184 i inne; A. Lewicka-Kamińska, Rzut oka na rozwój oprawy ksiażkowej w Krakowie, „Roczniki Biblioteczne" R. XVI, 1972, s. 53-54; I. Schunke, Krakauer Frührenaissanceeinbände, „Gutenberg Jahrbuch" 1973, s. 429-435, il. 2-3; E. Zwinogrodzka, Introduction, w: Poolse Boekbindkunst 1400-1800. Uit de Jagiellonski Bibliotheek, Krakow, Samenstelling E. Zwinogrodzka, P. Hordinski, J. Storm van Leeuwen, Koninklijke Bibliotheek, Den Haag 1990, s. 9; J. Storm van Leeuwen, The Golden Age of Bookbindings in Cracow 1400-1600, Exhibition Biblioteka Jagiellońska, 18-25 September 2011, Kraków 2011, s. 16-21, 28-30 i inne.

${ }^{41}$ M. Krynicka, Oprawy ksiażkowe z herbami ostatnich Jagiellonów w zbiorach Muzeum Narodowego w Krakowie, "Rozprawy i Sprawozdania Muzeum Narodowego w Krakowie" 1980, t. XII, s. 35, przypis 51. 
tzw. Mistrza Główek Anielskich, którego aktywność zamyka się wedle dotychczasowych hipotez pomiędzy latami około 1520 a $1546^{42}$. W świetle źródeł archiwalnych postać tę należałoby identyfikować z Maciejem z Przasnysza (zm. 1544/1545), którego bliskie związki z prominentnymi bibliofilami wynikały m.in. z zamieszkiwania blisko Wawelu, przy kolegiacie Wszystkich Świętych ${ }^{43}$. Ponadto introligator ten wyspecjalizował się w obsłudze biblioteki katedralnej, na której potrzeby wykonał m.in. oprawy dwóch mszałów zakupionych przez kapitułę ${ }^{44}$.

Dokładna analiza prac włączanych do jego oeuvre nasuwa jednak wątpliwości atrybucyjne, do których skłaniają obowiązujące w XVI wieku praktyki warsztatowe. Analogie formalne pomiędzy dziełami mogą stanowić bowiem konsekwencję wspólnej orientacji stylowej dwóch, a nawet więcej mistrzów introligatorskich działających równocześnie bądź po sobie $\mathrm{w}$ tym samym środowisku. Fakt naśladowania dzieł Macieja z Przasnysza przez innych, współczesnych mu introligatorów krakowskich był już akcentowany w literaturze ${ }^{45}$. Należy podkreślić, że - z pojedynczymi wyjątkami - ówczesnym północnoeuropejskim artystom wciąż obce było pojęcie plagiatu. W jeszcze większym stopniu odnosi się to do reprezentantów rzemiosła artystycznego. Z kolei identyczność narzędzi dekoracyjnych stosowanych na przestrzeni wielu lat mogła wynikać z powszechnej praktyki ich przechodzenia $z$ warsztatu do warsztatu, np. po śmierci pierwotnego posiadacza. I w tym miejscu konieczne jest zastrzeżenie: często wyciski tłoków łączone z jednym narzędziem dokonane są w rzeczywistości z jego repliki bądź replik. Ich liczebność na rynku

${ }^{42}$ L. Hajdukiewicz, op.cit., s. 184; Sztuka w Krakowie..., s. 49-50, 212, il. 99; Poolse Boekbindkunst..., s. 57-62, kat. 72-78, il. nienum.; O. Mazal, Einbandkunde, Wiesbaden 1997, s. 229; M. Krynicka, Bucheinbände, w: Polen im Zeitalter der Jagiellonen 1386-1572, Wien 1986, s. 499, 507; J. Storm van Leeuwen, op.cit., s. 30.

43 Wypisy źródłowe do dziejów Wawelu. Artyści i rzemieślnicy krakowscy w latach 1526-1535, oprac. B. Przybyszewski, t. 11, cz. 4, Kraków 1985, s. 126 (tamże odnośniki do poszczególnych archiwaliów). Na temat indywidualności twórczej Macieja z Przasnysza przygotowuję osobny artykuł.

${ }^{44}$ Wypisy źródłowe..., s. 126. Chodzi tu być może o mszał dla katedry wawelskiej, którego egzemplarze znane są dziś m.in. w charakterystycznych oprawach z dekoracją architektoniczną - jedną z nich sporządzono dla Zygmunta Starego (zob. R. Kotula, Właściciele rękopisów i starodruków zbiorów wielkopolskich Z. Czarneckiego mieszczacych się obecnie w "Baworovianum" we Lwowie, Lwów 1929, s. 1, il. 1-2), a drugą dla bpa Tomickiego (zob. Oprawy polskie. Wystawa zorganizowana przez Biblioteke Narodowa i Oddział Warszawski Towarzystwa Przyjaciół Ksią̇̇ki, listopad-grudzień 1987, Warszawa 1987, kat. 23, s. 26, il. 3).

45 Sztuka w Krakowie..., s. 49-50. 
introligatorskim zależała zaś głównie od zapotrzebowania. Wytwórcy narzędzi umiejętnie się do niego dostosowywali, czego wyrazem było choćby szerokie rozpowszechnienie w XVI wieku łudząco podobnych do siebie radełek z ikonografią religijną oraz all'antica, a nawet charakterystycznych tzw. radełek jagiellońskich. Rozwianie powyższych wątpliwości wymagałoby systematycznych badań komparatystycznych, których niezbędnym warunkiem jest zinwentaryzowanie zasobu introligatorskiego rodzimych bibliotek ${ }^{46}$.

Kontrowersje opisane wyżej nie omijają zresztą i dzieł wykonywanych dla Łaskiego. Dowodzi tego znajdująca się w British Library oprawa dwóch druków Erazmiańskich z 1526 i 1527 roku, którą sporządzono z typowej dla warsztatu krakowskiego mistrza jasnej skóry $(\text { il. } 8)^{47}$. Jej okładziny otacza kilkuliniowa rama strychulcowa $\mathrm{z}$ wyciskami inskrypcyjnymi u góry i u dołu, za którą następuje ku wewnątrz złocona (obecnie sczerniała) rama arabeskowa wyciśnięta z podłużnych tłoków. W zwierciadle widnieje herbowy superekslibris o analogicznej, lecz bardziej uproszczonej formie niż w poprzednich oprawach, a także rozmieszczone $\mathrm{w}$ narożnikach wyciski trójlistka $\mathrm{z}$ nietypowym, zakręconym ogonkiem. Kompozycja dekoracji tej oprawy wespół z zastosowanymi formami zdobień znakomicie wyraża nurt italiani$\mathrm{zmu} \mathrm{w}$ krakowskim introligatorstwie, reprezentowany przez Macieja z Przasnysza. Podobny schemat dekoracji reprezentują bowiem w tym samym okresie np. oprawy weneckie, bolońskie i mediolańskie (il. 9) ${ }^{48}$. Elementem dekoracyjnym nakazującym jednak ostrożność atrybucyjną jest superekslibris. Pomimo podobieństwa z użytym w podobnym czasie superekslibrisem z oprawy poznańskiej jest to bezsprzecznie inne dzieło, noszące znamiona uproszczonej kopii. Jednocześnie należałoby odrzucić domniemanie, jakoby superekslibris ten zastąpił w danym momencie wyeksploatowany tudzież uszkodzony klocek z oprawy

${ }^{46}$ Krok w tym kierunku wykonała w 2011 roku Biblioteka Poznańskiego Towarzystwa Przyjaciół Nauk, inicjując pierwszą w Polsce elektroniczną bazę opraw zabytkowych (www.ptpn.ig.pl/oprawy/index_en.php, red. A. Wagner (do 15 grudnia 2011 roku) [dostęp: 10.12. 2011]). Znajdują się w niej także prace atrybuowane Maciejowi z Przasnysza (określanemu jako Mistrz Główek Anielskich).

47 H.M. Nixon, op.cit., s. 65; M.M. Foot, op.cit., s. 491, il. na s. 490; http://www. bl.uk/catalogues/bookbindings/LargeImage.aspx?RecordId=020-000004638\&ImageId=41924\&Copyright=BL [dostęp: 20.12.2011].

48 Zob. np. P. Quilici, Legature antiche e di pregio. Sec. XIV-XVIII, Catalogo, t. 1, Roma 1995, kat. 264, 266, 291, 300; t. 2, Roma 1995, il. 110-111, 503 (oprawy weneckie), 124 (oprawa bolońska), 128 (oprawa z Cremony lub Mediolanu). 


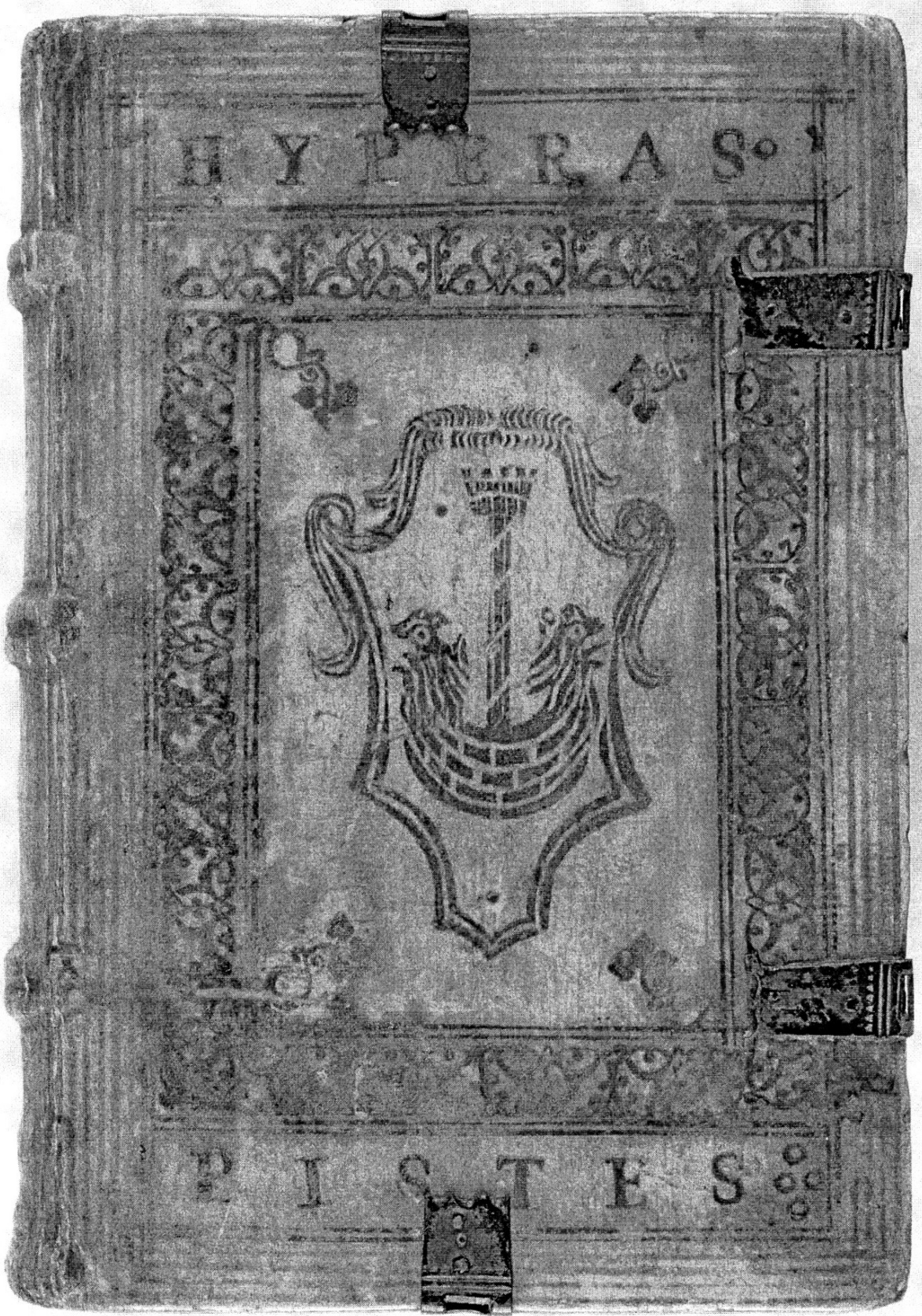

Il. 8. Maciej z Przasnysza (Mistrz Główek Anielskich)?, Stanisław z Białej?, oprawa w typie włoskim (górna okładzina), Kraków, prawdopodobnie 1526

Źródło: http://www.bl.uk/catalogues/bookbindings/LargeImage.aspx?RecordId=020-000004638\& ImageId=41924\&Copyright=BL [dostęp: 15.11.2011]. 


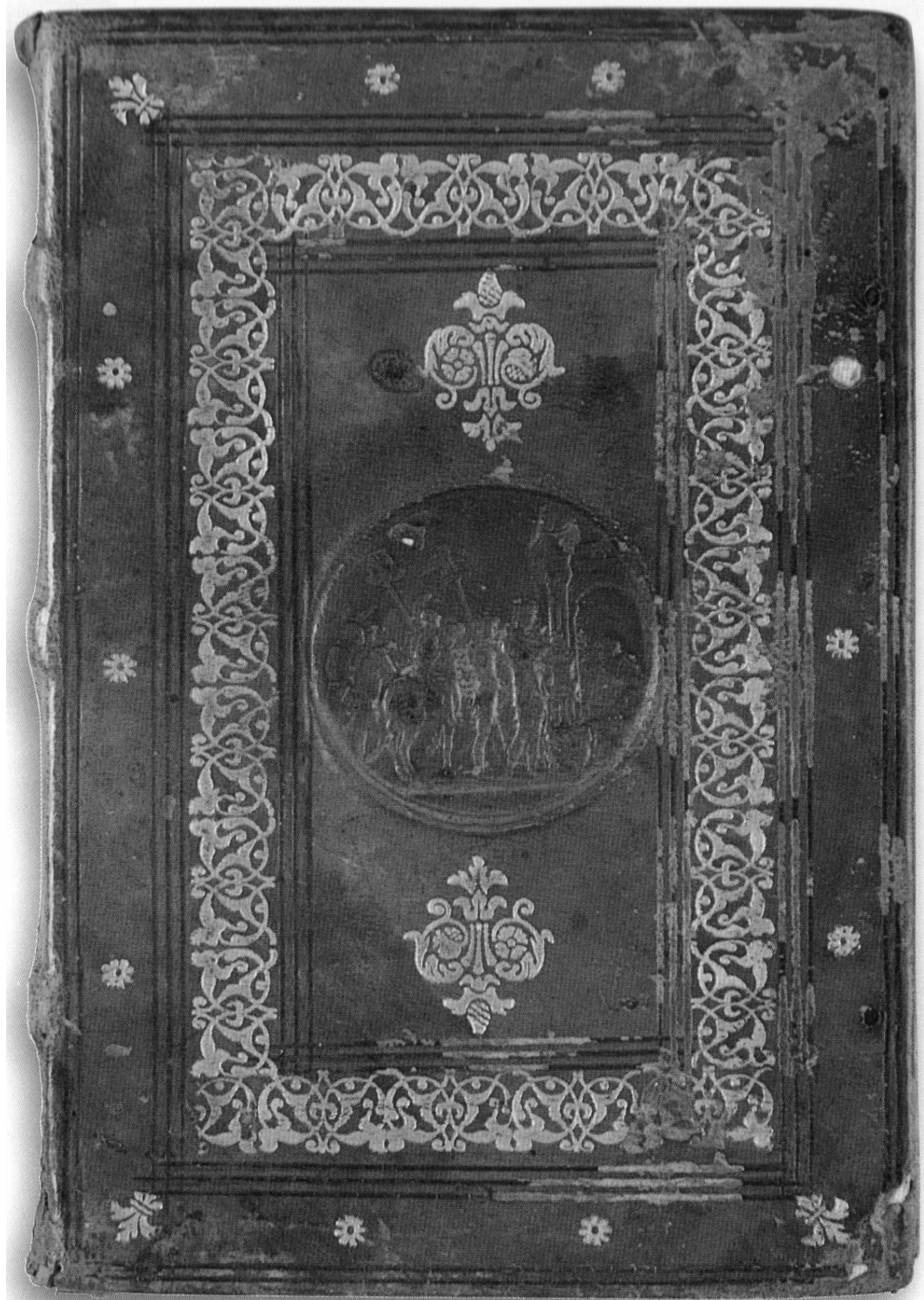

I1. 9. Introligator anonimowy, oprawa a cammeo (górna okładzina), Mediolan, po 1516 Źródło: G. Bologna, Legature, Milano 1998. 
poznańskiej. Jego dobre jakościowo wyciski znane są bowiem z opraw znacznie późniejszych, nawet z lat 40 . XVI wieku ${ }^{49}$. Równoległe stosowanie dwóch niemal identycznych matryc superekslibrisowych w jednym warsztacie $w$ tym samym czasie dowodziłoby zaś trudnej do przyjęcia rozrzutności introligatora. $Z$ tego względu bardziej prawdopodobne wydaje się zlecenie przez Łaskiego wykonania opraw dwom warsztatom, operującym italianizującym językiem formalnym, z których ów drugi posługiwał się kopią dzieła z konkurencyjnej pracowni. Mógł to być znakomity introligator krakowski Stanisław z Białej vel Mistrz Medalionów, który od drugiego dziesięciolecia XVI wieku specjalizował się w wyraźnie italianizujących dziełach ${ }^{50}$.

Mimo wątpliwości odnoszących się do oprawy ze zbiorów brytyjskich, analogiczne materiały i rozwiązania techniczno-formalne $\mathrm{w}$ znanych $\mathrm{z}$ literatury oprawach dla Łaskiego pozwalają $\mathrm{w}$ nich widzieć jednego twórcę. Za warsztatową tożsamością prac przemawia biegłe posługiwanie się ich wykonawcy rozmaitymi typami dekoracji wzorowanymi na dziełach włoskich. Należy do nich zwłaszcza tzw. typ architektoniczny odznaczający się okazałością formy i profuzją motywów dekoracyjnych. W oprawach dla Łaskiego zastosowano jeden $\mathrm{z}$ jego wariantów, którego istotą jest motyw portalu wkomponowany w obszerne zwierciadło okładzin. W parokrotnie reprodukowanym i opisywanym egzemplarzu z The Library of Queens' College w Cambridge $(1527)^{51}$ oraz późniejszym egzemplarzu z Biblioteki Jagiellońskiej (po 1529) (il. 10) ${ }^{52}$ prześwit portalu ujmują dwie kolumny (bądź półkolumny dostawione do ściany). Podtrzymują one belkę oraz półkolisty tympanon, po którego bokach widnieją krótsze kolumny (lub - analogicznie jak wyżej - półkolumny) wspierające gzyms. Strefę między podporami architektonicznymi wypełnia wycisk prostokątnej plakiety bądź pokaźny pierścień ornamentalny mieszczący superekslibris. Pole tympanonu

\footnotetext{
${ }^{49}$ Np. Oprawy dla Macieja Śliwnickiego, sygn. Biblioteki Uniwersytetu Warszawskiego: Sd. 608.877 (zob. M. Sipayłło, Polskie superexlibrisy XVI-XVII wieku w zbiorach Biblioteki Uniwersyteckiej w Warszawie, Warszawa 1988, s. 42, tabl. 5) oraz sygn. Biblioteki Seminarium Duchownego we Włocławku: XVI. F. 4141, XVI. F. 4483-4485, XVI. F. 4568-4469 (zob. K. Rulka, Superekslibrisy w zbiorach Biblioteki Seminarium Duchownego we Włocławku, "Studia Włocławskie” 2003, nr 6, s. 532-533).

50 O twórczości Stanisława m.in. w: A. Lewicka-Kamińska, Stanisław, introligator krakowski z 1. połowy XVI w., „Biuletyn Biblioteki Jagiellońskiej” 1980, nr 1/2, s. 31-41, il. 1-6; J. Storm van Leeuwen, op.cit., s. 29-30, 112, tabl. nienum.

${ }^{51}$ H.M. Nixon, op.cit., s. 64-65; H.P. Jürgens, Johannes a Lasco..., s. 136-137, kat./ il. 2.3.1.

${ }^{52}$ H.P. Jürgens, Johannes a Lasco..., s. 140-141, kat./il. 2.3.3.
} 


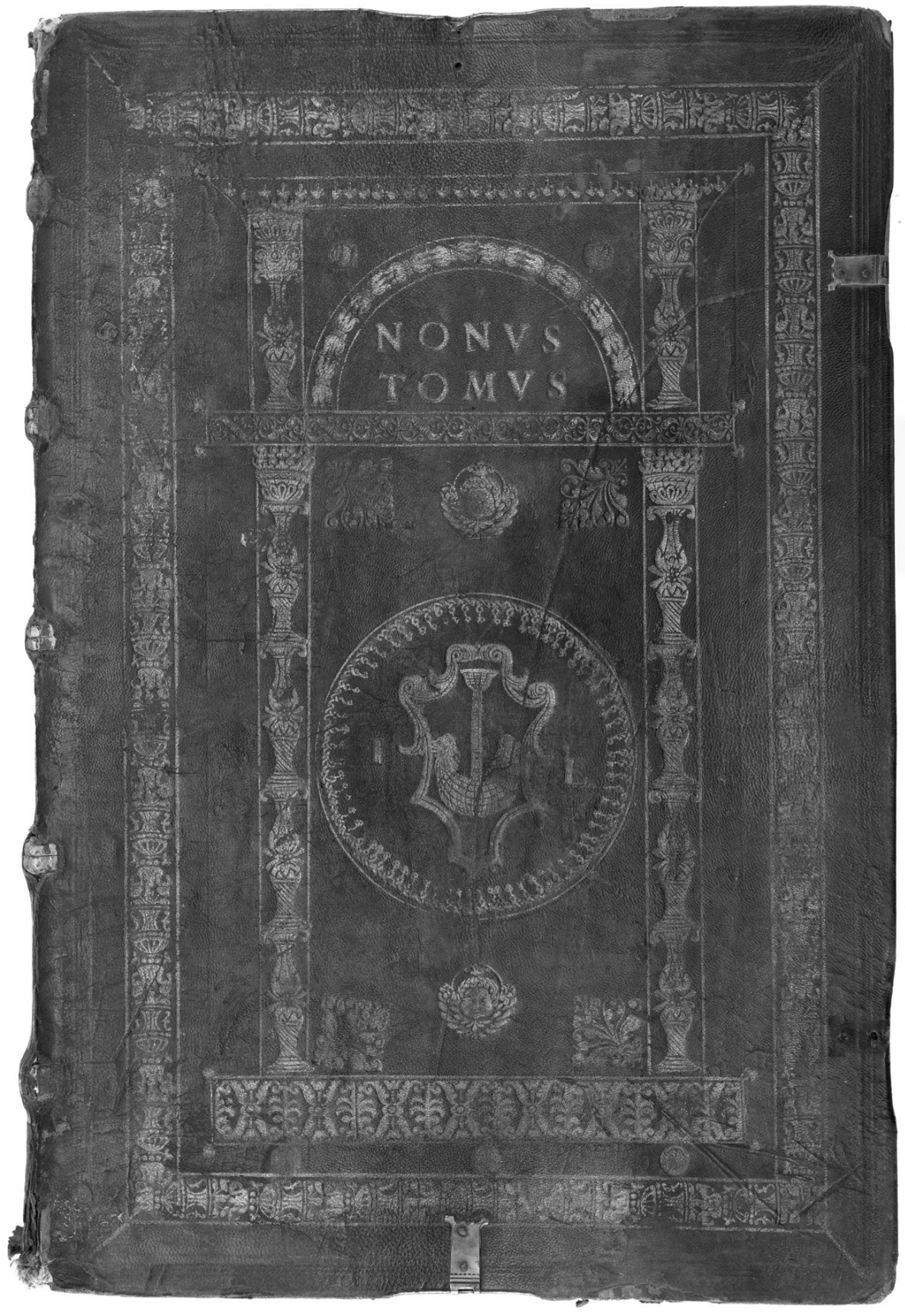

Il. 10. Maciej z Przasnysza (Mistrz Główek Anielskich), oprawa w typie architektonicznym (górna okładzina), Kraków, 1529

Źródło: zbiory Biblioteki Jagiellońskiej; fot. (C) Biblioteka Jagiellońska. 
na górnej okładzinie rezerwowane jest zaś na inskrypcję odnoszącą się do zawartości woluminu. O misterności architektonicznych struktur dekoracji opraw świadczy ukształtowanie ich z szeregu wycisków tłoków zdobniczych obwiedzionych konturowymi liniami. Ów typ dekoracyjny wywodzi się $\mathrm{z}$ tradycji introligatorstwa włoskiego drugiej połowy XV wieku. Pierwotnie forma architektonicznego motywu była skromniejsza, przypominała raczej sarkofagi antyczne ${ }^{53}$. Oprócz dzieł włoskich ukazują go także oprawy węgierskie, w tym anonimowego Mistrza Korwina działającego około 1490 roku w Budzie ${ }^{54}$. Z czasem dekoracja takich opraw wyewoluowała do form bardziej rozbudowanych, czego przykład stanowią oprawy bolońskie z pierwszej ćwierci XVI wieku (il. 11) ${ }^{55}$. Najdoskonalszymi wytworami tego typu z epoki odrodzenia są oprawy sporządzone w Paryżu dla Jeana Groliera i Thomasa Mathieu ${ }^{56}$.

Kolejny typ italianizującej dekoracji stosowany przez krakowskiego mistrza znany jest z egzemplarza oprawy przechowywanego w Johannes a Lasco Bibliothek w Emden ${ }^{57}$. Opiera się on na prostokątnej ramie, w której zwierciadło wpisana jest romboidalna, mniejsza rama (il. 12). W połowie długości boków łączy się ona z narożnikami prostokątnej ramy za pomocą ukośnych listew. Wszystkie elementy ukształtowane są z podwójnych wycisków strychulca bądź filety, pomiędzy którymi ciągnie się ornament tralkowy. Pola powstałe wskutek połączeń listew zdobią zaś wyciski floralnych tłoków. Centrum zwierciadła wyznacza superekslibris Łaskiego o formie analogicznej do opraw z dekoracją architektoniczną. Przegląd włoskiego introligatorstwa renesansowego udowadnia wierne wzorowanie się krakowskiego mistrza na dziełach powstających od schyłku XV wieku. Dowodów na to dostarczają np. oprawy inkunabułów

53 Typ architektoniczny opraw omówiony jest m.in. w: T. De Marinis, La legatura..., t. 3, s. 51-54, tabl. B1, C1, CCCCXXII, CCCCLXXXVII-CCCCXCI; A. Hobson, Humanists..., s. 68-72, 154-162, il. 57-60/a-d, 123-127; F. Macchi, L. Macchi, Dizionario..., s. 20, 424; A. Hobson, A group of Venetian fifteenth century bindings, "Einband Forschung" 1999, z. 4, s. 2-5, il. nienum.

54 I. Schunke, Vom Stil der Corvineneinbände, „Gutenberg Jahrbuch” 1944/49, s. 216-220, il. 8; O. Mazal, Europäische..., s. 44-45, il. 90; idem, Königliche Bücherliebe. Die Bibliothek des Matthias Corvinus, Graz 1990, s. 69, 73, il. 30.

55 Zob. np. F. Macchi, L. Macchi, Atlante..., tabl. 2, 3; A. Hobson, L. Quaquarelli, op.cit., s. 69 , il. 17.

56 G.D. Hobson, Maioli, Canevari and others, London 1926, s. 18-33, tabl. 19-24; R. Devauchelle, La reliure en France de ses origines à nos jours, t. 1: Des origines à la fin du XVIIe siècle, Paris 1959, s. 88, tabl. XXXVII; The British Museum. Bookbindings..., s. $44-45$, kat./il. 87.

${ }^{57}$ Opis i reprodukcja w: H.P. Jürgens, Johannes a Lasco..., s. 10, 138-139, kat./il. 2.3.2. 


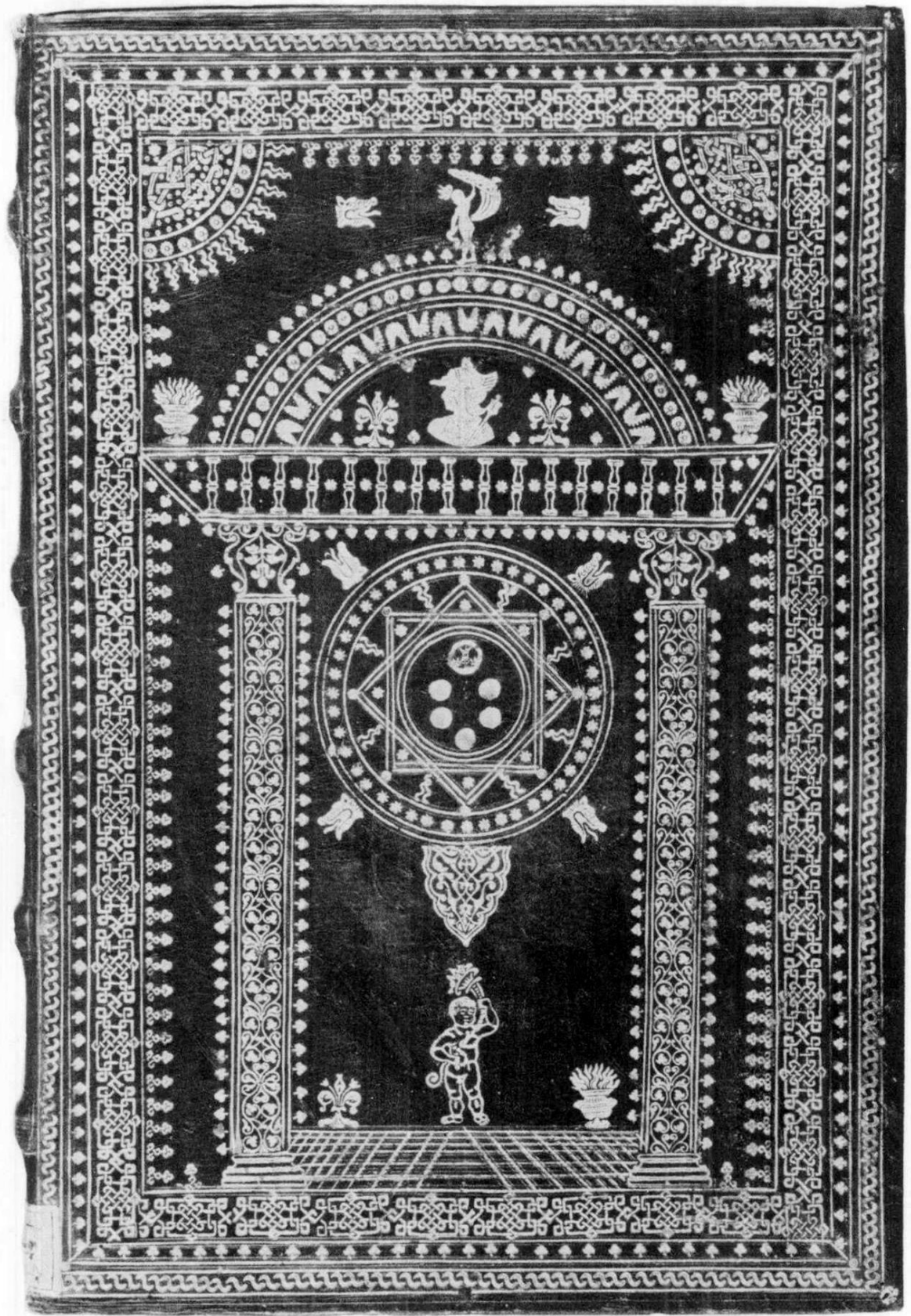

Il. 11. Introligator anonimowy, oprawa w typie architektonicznym (górna okładzina), Bolonia, po 1519

Źródło: T. De Marinis, La legatura artistica in Italia nei secoli XV e XVI, t. 1, Firenze 1960. 


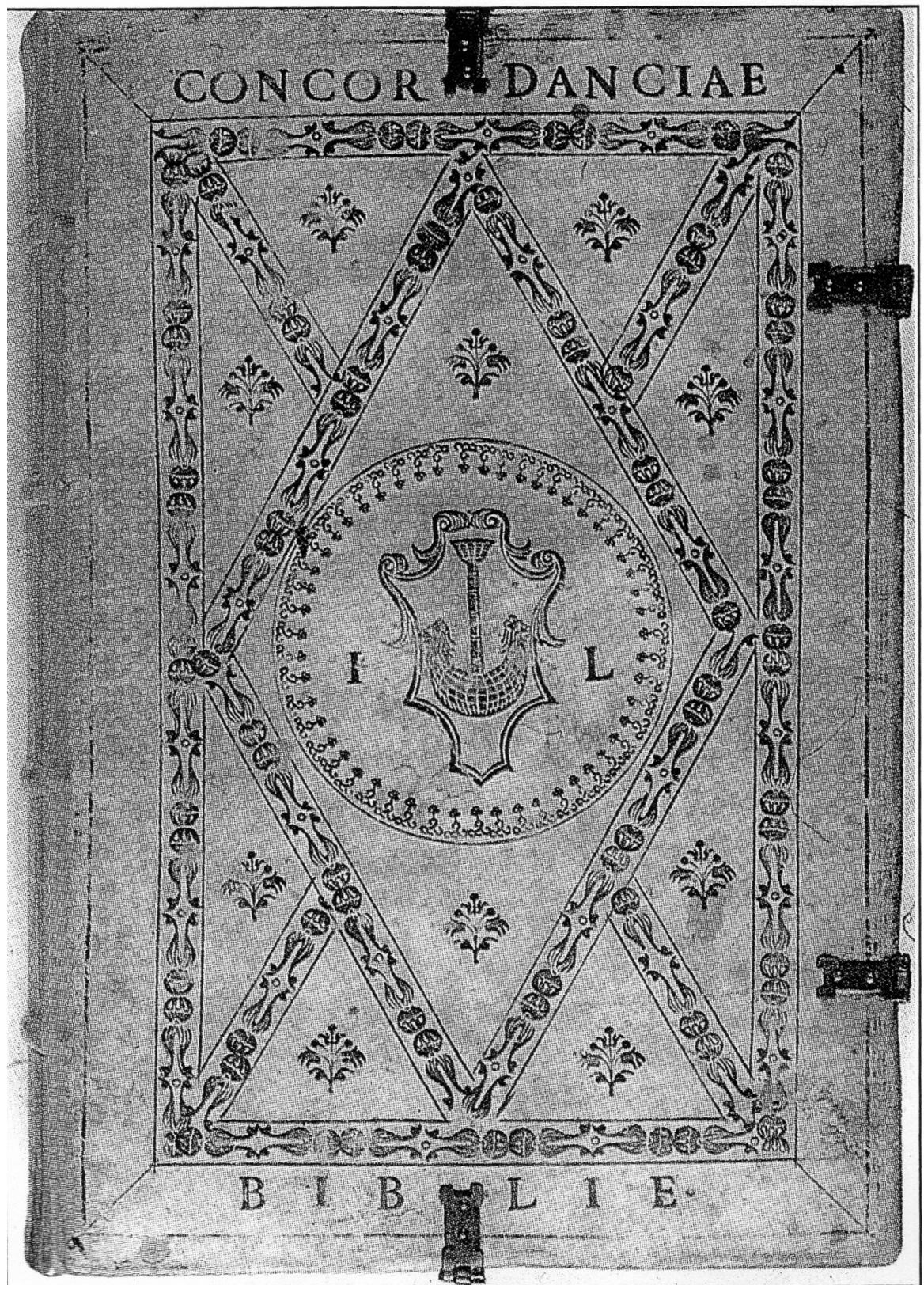

Il. 12. Maciej z Przasnysza (Mistrz Główek Anielskich), oprawa w typie włoskim (górna okładzina), Kraków, 1527?

Źródło: zbiory Johannes a Lasco Bibliothek w Emden; fot. wg H.P. Jürgens, Johannes a Lasco. Ein Leben in Büchern und Briefen. Eine Ausstellung der Johannes a Lasco Bibliothek, Wuppertal 1999. 
słynnego krakowskiego bibliofila Mikołaja Czepla (1452-1518) (il. 13) ${ }^{58}$. Na ciemnej skórze okładziny wyciśnięto kilkuliniowe ramy strychulcowe wypełnione m.in. motywami plecionkowymi typu nodo (zewnętrzna rama). W polach wyznaczonych przez ukośne listwy oraz w zwierciadle rombu rozmieszczono zaś symetrycznie motywy ornamentalne.

Podobną formułę dekoracji reprezentuje oprawa druku weneckiego oraz oprawa Breviarum Romanum reprodukowane przez Tomassa De Marinisa, w których stykające się ze sobą ramy wypełniają różne ornamenty ${ }^{59}$. Charakterystyczna dla ornamentyki włoskiej arabeska widnieje w ramach weneckiej oprawy druku aldyńskiego z 1514 roku $^{60}$. Bolońska oprawa $\mathrm{tzw}$. Drugiego introligatora S. Salvatore z lat 20.-30. XVI wieku ukazuje wariant wymienionych kompozycji, w którym ukośne linie przecinają się $\mathrm{w}$ centrum rombu, dzieląc go na cztery mniejsze pola ${ }^{61}$. Podobną dekorację do dzieła z Biblioteki Uniwersyteckiej w Poznaniu ma zaś oprawa znana $\mathrm{z}$ francuskiego rynku antykwarycznego, którą sporządzono prawdopodobnie w latach 30. XVI wieku. Jej odmienności sprowadzają się głównie do zastosowania wąskich listew łączących romb z prostokątem ${ }^{62}$. Oba ostatnie dzieła wskazują na ciągłą popularność tego wzorca w Italii w drugiej ćwierci XVI wieku.

Potwierdzałoby to zatem przyswajanie przez Macieja z Przasnysza bieżących tendencji włoskiego introligatorstwa. Odnosi się to także do wykonawcy narzędzi introligatorskich, którego należałoby upatrywać w kręgu krakowskich rytowników tudzież złotników ${ }^{63}$. Najpewniej lokalnym wyrobem była też matryca superekslibrisu z herbem Korab. Sposób opracowania detali tarczy i godła sygnalizuje, że sporządzono ją w drewnianym klocku - jednym z niezliczonych, w które zaopatrywały się polskie warsztaty introligatorskie XVI-XVII wieku ${ }^{64}$. Wzorców do kształtu

58 Zob. A. Lewicka-Kamińska, Renesansowy księgozbiór..., kat. 52/s. 72, tabl. 5, zob. też: kat. 107/s. 89, kat. 127/s. 95.

59 T. De Marinis, La legatura..., t. 1, tabl. XL/240, CLXXV/1094.

60 G. Mazzucco, Legature rinascimentali di edizioni di Aldo Manuzio, w: Aldo Manuzio e l'ambiente veneziano 1494-1515, red. S. Marcon, M. Zorzi, Venezia 1994, il. na s. 151 (prawy narożnik u dołu), kat. 142.

${ }^{61}$ A. Hobson, L. Quaquarelli, op.cit., s. 85, il. 33.

${ }^{62}$ Catalogue de reliures du XVe au XIX siècle, en vente a la Librarie Gumuchian $\mathcal{E}$ Cie, Paris 1931, s. 35, tabl. XXIX/62.

${ }^{63}$ Zob. Sztuka w Krakowie..., s. 50. O praktyce zaopatrywania się XVI-wiecznych introligatorów środkowoeuropejskich w narzędzia zdobnicze w: B. Nuska, op.cit., s. 140-141.

${ }^{64}$ A. Wagner, Oprawy ksiag..., s. 183-185; idem, Die goldene Zeit des polnischen Supralibros, materiały kolokwium bibliologicznego Der Weg des Buches, Bratysława, 28-30 września 2009 (w druku). 
tarczy dostarczały zaś w latach 20. XVI wieku nie tylko wspomniane już włoskie iluminacje, grafika książkowa oraz superekslibrisy, ale także dzieła lokalnej rzeźby ${ }^{65}$, grafiki książkowej ${ }^{66}$, iluminatorstwa ${ }^{67}$ oraz ekslibrisu $^{68}$. Na podstawie znanych dziś zabytków introligatorstwa można też stwierdzić, że wzór testa di cavallo był stosowany już w pierwszych latach XVI wieku w krakowskich superekslibrisach. Wskazuje na to introligatorski tłok superekslibrisowy, przedstawiający herb Sulima, wykopany w Krakowie w 1910 roku podczas prac ziemnych wraz z innymi narzędziami z gotyckimi i renesansowymi motywami dekoracyjnymi ${ }^{69}$. Podobny superekslibris z tym samym herbem znany jest z późnogotyckiej oprawy inkunabułu w Bibliotece Czartoryskich (il. 7) ${ }^{70}$. Wzbogacenie obu dzieł wyciskami łłoków z motywami insygniów biskupich sygnalizuje,

${ }^{65}$ Zaliczają się do nich m.in.: herb z brązowego epitafium Kallimacha z kościoła Dominikanów w Krakowie (Wit Stwosz - projekt, pracownia Petera Vischera - odlew, 1496-ok. 1500), tarcze w panopliach kasetonów i płycinach pilastrów nagrobka Jana Olbrachta (Franciszek Florentczyk, 1502-1505), tarcze w kasetonach baldachimu nagrobka Władysława Jagiełły (warsztat Bartłomieja Berrecciego, 1519-1524), tarcza z gmerkiem w tzw. oratorium Kaufmanów w kościele Mariackim w Krakowie (jw., 1520), herb królewski i tarcze z zewnętrznej dekoracji okien kaplicy Zygmuntowskiej (jw., przed 1526).

${ }^{66}$ Zob. np. rycina z dwoma herbami na stronie tytułowej Prognosticon Vratislaviense Gandolphusa Grusseniusa (Kraków, Florian Ungler nakładem Jana Hallera, 1515/1516; K. Piekarski, Katalog Bibljoteki Kórnickiej, t. 1: Polonica XVI-go wieku, Kórnik 1929, kat. 567, s. 74, il. na s. 99), rycina z herbem na stronie tytułowej wiersza Andrzeja Krzyckiego na ślub Zygmunta Starego z Bona, wydanego przez Jana Hallera w 1518 roku (P. Chmielowski, Historya literatury polskiej od czasów najdawniejszych do końca wieku XIX, t. 1, Lwów-Warszawa [po 1904], il. na s. 167); drzeworyt w stemmacie na herb królowej Bony z druku Hieronima Wietora wydanego w 1523 roku (F. Pilarczyk, Stemmata w drukach polskich XVI wieku, Zielona Góra 1982, il. 14, s. 170-171).

${ }^{67}$ Swobodne naśladownictwa tarcz testa di cavallo widnieją już w gotyckim Kodeksie Baltazara Behema (Kraków 1505-1512). Wierne włoskim pierwowzorom są zaś iluminowane tarcze z Pontyfikału Erazma Ciołka (karta z Intronizacja króla polskiego, Kraków 1510-1515) oraz Mszału Ciołka (karta 121V, Kraków 1515-1518); zob. np. B. Miodońska, Małopolskie malarstwo ksiażkowe 1320-1540, Warszawa 1993, s. 178, 183, il. 229, 239, 274.

${ }^{68}$ Pewne zależności od tradycji włoskiej wykazuje tarcza herbu w ekslibrisie „,anonima herbu Prus I" identyfikowanego z Janem Szykowskim i datowanego ogólnie przed 1530 rokiem, zob. m.in. Z. Ameisenowa, Dwa nieznane polskie znaki książkowe z XVI wieku, Kraków 1947, s. 5-16, il. 1; S.J. Gruczyński, Ekslibris Jana Szykowskiego, „Roczniki Biblioteczne" R. XI, 1967, s. 55-61, il. 1; A. Lewicka-Kamińska, Ekslibris Anonima herbu Prus I, „Biuletyn Biblioteki Jagiellońskiej” R. XX, 1970, nr 1/2, s. 141-146, il. 12.

${ }^{69}$ A. Chmiel, Z dawnych opraw introligatorskich, „Exlibris” R. I, 1917, z. 1, s. 15, il. 8.

${ }^{70}$ Sygn. Biblioteki Czartoryskich: Inc 13 IV; zob. też A. Chmiel, Z dawnych opraw..., s. 15 , il. 9 . 


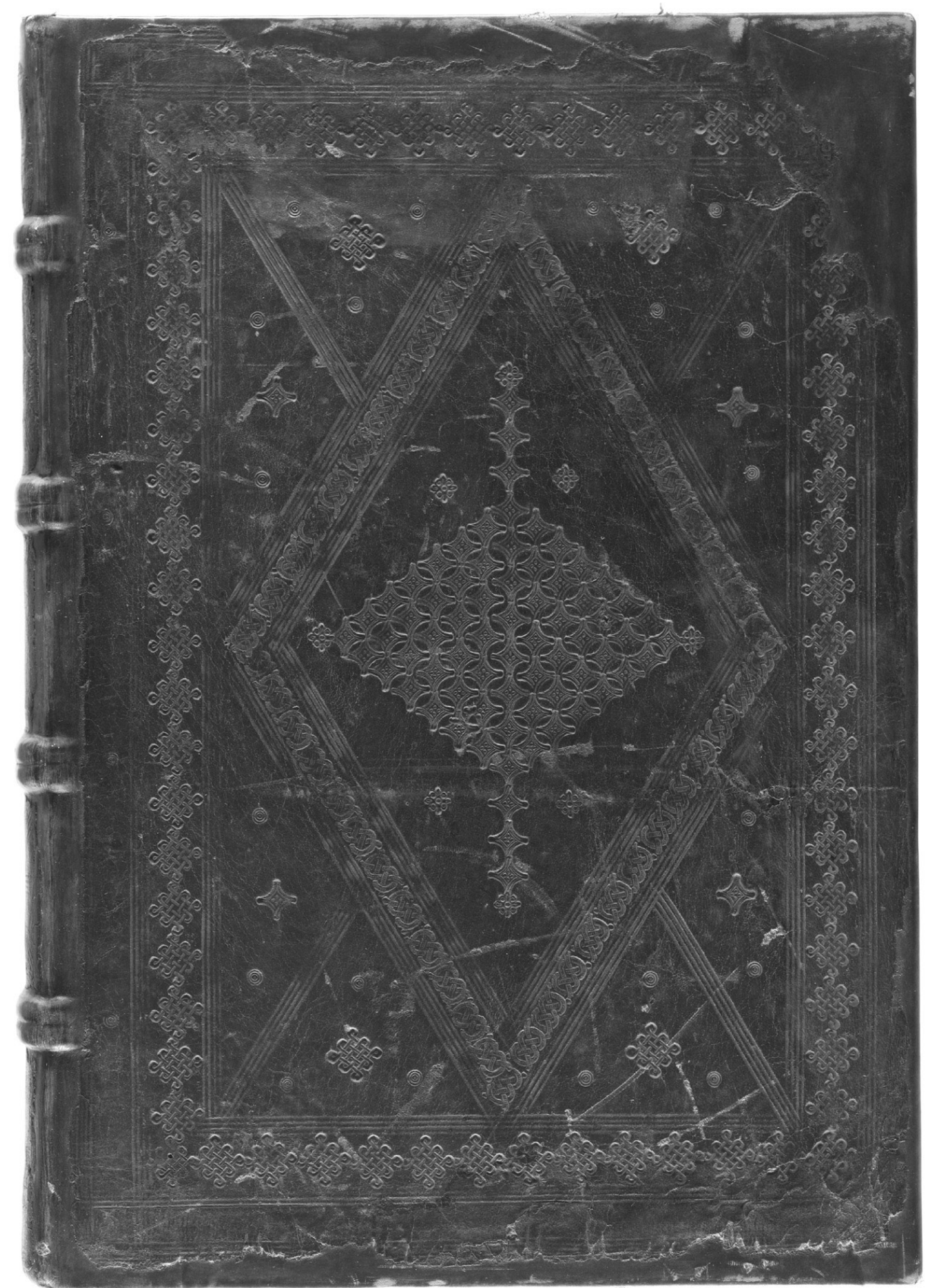

Il. 13. Introligator anonimowy, oprawa druku (górna okładzina), Wenecja?, lata 90. $\mathrm{XV}$ wieku

Źródło: zbiory Biblioteki Jagiellońskiej; fot. (C Biblioteka Jagiellońska. 
że wykonano je dla wytrawnego bibliofila - bpa płockiego Erazma Ciołka (zm. 1522) ${ }^{71}$. Za włoskim importem może przemawiać jedynie forma tłoków literniczych. Zgrabne proporcje ich antykwowego kroju zdecydowanie odbiegają bowiem od liternictwa wczesnorenesansowego, a nawet gotyckiego (tekstura), stosowanego w krakowskim introligatorstwie jeszcze w drugim dziesięcioleciu XVI wieku.

Wypada w tym miejscu podkreślić, że zarysowany wyżej dialog Macieja z Przasnysza z współczesnym mu repertuarem zdobniczym introligatorstwa włoskiego powodował wieloletnie spekulacje na temat pochodzenia wykonawcy opraw. Sprzyjał temu fakt ogólnie znanych związków krakowskiego dworu królewskiego z Italią oraz renesansowo zorientowanym, węgierskim dworem królewskim w Budzie. Już przed wojną Geoffrey D. Hobson upatrywał lokalizacji warsztatu wykonawcy opraw dla Łaskiego w Budzie bądź Krakowie ${ }^{72}$. Ilse Schunke w publikacji dotyczącej ksiąg Macieja Korwina przytoczyła opisaną już oprawę architektoniczną dla Łaskiego z Cambridge, przypisując ją gnieźnieńskiemu introligatorowi przybyłemu prawdopodobnie z $\mathrm{Czech}^{73}$. Bohumil Nuska rozważał w kontekście opraw dla Łaskiego możliwość wykonywania opraw w Krakowie przez mediolańskich introligatorów ${ }^{74}$. Howard M. Nixon, powołując się na opinię Schunke, skojarzył italianizm w pracach krakowskiego warsztatu ze ślubem Zygmunta Starego z Boną - córką Gian Galeazzo Sforzy ${ }^{75}$. Ku związkom introligatora z dworem królowej Bony skłaniał się też Henning P. Jürgens ${ }^{76}$. Przed określeniem pochodzenia introligatora wzbraniała się zaś Maria Krynicka, akcentując jedynie imitowanie przez niego opraw północnowłoskich, weneckich i mediolańskich ${ }^{77}$.

Istotnie, badania nad mieszczaństwem stolicy Królestwa potwierdzają stały napływ do niej Włochów od schyłku XIV wieku, zintensyfikowany $\mathrm{w}$ pierwszej połowie XVI stulecia ${ }^{78}$. Spektakularny sukces włoskich

${ }^{71}$ A. Chmiel (Z dawnych opraw...) przypuszczał, że znaleziony tłok superekslibrisowy mógł być wykonany na polecenie innego krakowskiego biskupa pieczętującego się Sulimą - Piotra Gamrata (zm. 1545).

72 G.D. Hobson, Bindings..., s. 65.

73 I. Schunke, Vom Stil..., s. 219.

${ }^{74}$ B. Nuska, op.cit., s. $179-180$.

${ }^{75}$ H.M. Nixon, op.cit., s. 67.

${ }^{76}$ H.P. Jürgens, Johannes a Lasco..., s. 10, 136, 138.

77 M. Krynicka, Bucheinbände, s. 499, 507.

${ }^{78}$ Zob. np. W. Tygielski, Włosi w Polsce XVI-XVII wieku, Warszawa 2005, s. 168-323 i inne; K. Follprecht, Włosi w elicie politycznej Krakowa do połowy XVII w. Topografia siedzib, w: Elita władzy miasta Krakowa i jej zwiazki z miastami Europy w średniowieczu i epoce nowożytnej (do połowy XVII wieku), red. Z. Noga, Kraków 2011, s. 251-265. 
rzeźbiarzy i muratorów działających na Wawelu od początku XVI wieku mógł stanowić magnes także dla uzdolnionego introligatora. Sprzyjała temu postawa królowej Bony, która „by zadowolić swe upodobania, sprowadzała, co zrozumiałe, artystów z rodzinnej Italii, tworząc im na polskim dworze odpowiednio atrakcyjne warunki"79. Osiadłszy w lokalnych strukturach cechowych bądź zostając serwitorem królewskim, włoski introligator miałby możliwość zaopatrywania zarówno zleceniodawców szlachecko-mieszczańskich, jak i bardziej wymagających klientów z kręgu elity politycznej. Dotychczasowe analizy składu osobowego dworu królowej Bony nic jednak nie mówią o introligatorze ${ }^{80}$. Żadnego włoskiego introligatora nie wymieniają także Księgi przyjęć do prawa miejskiego w Krakowie z lat 1507-1572 ${ }^{81}$. Trudno zaś wyobrazić sobie, by długotrwale funkcjonujący $\mathrm{w}$ mieście rzemieślnik takiego prawa nie otrzymał. Wypada nadmienić, że introligatorów brak też w zestawieniach włoskich rzemieślników działających na dworze Zygmunta Augusta ${ }^{82}$. Niewiele wnoszą w tej kwestii również dokumenty cechowe z drugiej połowy XVI wieku, wymieniające krakowskich introligatorów i ich czeladników. Wskazują one jedynie na absolutną dominację rzemieślników pochodzących z ziem polskich i krajów niemieckich, obok których ani razu nie pojawia się przybysz z Włoch ${ }^{83}$. Należy zatem, wobec zidentyfikowania Macieja z Przasnysza jako wykonawcy opraw łączonych dotychczas $z$ anonimowym Mistrzem Główek Anielskich, odrzucić hipotezę nie tylko o włoskim pochodzeniu tego mistrza, ale też o funkcjonowaniu w Krakowie epoki renesansu jakiegokolwiek włoskiego introligatora.

W jaki więc sposób ów lokalny twórca przyswoił sobie repertuar form stosowanych we Włoszech? Wobec szczątkowej znajomości jego biografii należy dopuścić kilka możliwości. Przede wszystkim fakt narastającej popularności włoskich formuł dekoracji introligatorskiej mógł skłonić Macieja - jeszcze jako czeladnika introligatorskiego - do ich poznania w trakcie statutowej wędrówki. Okolicznością sprzyjającą introligatorskiej peregrynacji do Italii mogło być mediolańskie środowisko skupione wokół królowej. Motywująca do zmian formalnych w dekoracji opraw

${ }^{79}$ W. Tygielski, op.cit., s. 192.

${ }^{80}$ D. Quirini-Popławska wymienia spośród reprezentantów rzemiosł artystycznych jedynie pokaźną grupę złotników oraz hafciarzy (op.cit., s. 49-51, 56-57).

81 Zob. A. Kiełbicka, Z. Wojas, Księgi przyjęć do prawa miejskiego w Krakowie 1507-1572, Kraków 1993.

${ }^{82}$ W. Tygielski, op.cit., s. 311-314.

${ }^{83}$ A. Chmiel, Introligatorzy cudzoziemcy i zamiejscowi w Krakowie w latach 1574-1646, „Exlibris” 1929, t. 7, z. 2, s. 91-98; zob. też: A. Kiełbicka, Z. Wojas, op.cit., s. 6, 23, 32, $68,72,81$ i inne. 
zapewne była też presja klientów, stopniowo odrzucających anachroniczny język formalny gotyku. Pobyt we Włoszech gwarantował powrót $\mathrm{z}$ cennym bagażem doświadczenia zawodowego, z nowatorskimi projektami opraw, jak i z nabytymi narzędziami zdobniczymi o renesansowej formie. Należy jednak przypomnieć, że krakowskim introligatorem posługującym się zaawansowanymi formami włoskiego renesansu był już w drugiej dekadzie XVI wieku Stanisław z Białej ${ }^{84}$. Wobec znacznego podobieństwa niektórych jego dzieł do dorobku - działającego od trzeciej dekady XVI wieku - Macieja z Przasnysza uprawnione byłoby uznanie ich za mistrza i ucznia. Po usamodzielnieniu się drugiego z nich niewykluczona była kooperatywa obu mistrzów, sprowadzająca się np. do udostępniania sobie niektórych narzędzi zdobniczych, zaś po śmierci Stanisława - ich przejęcia tudzież zakupu. W obliczu wciąż słabej znajomości ówczesnych krakowskich introligatorów wypada też zastrzec, że szybkie rozpowszechnianie się nowych wzorców dekoracji opraw w trzeciej dekadzie XVI wieku mogło następować również dzięki innym, wciąż nieokreślonym twórcom.

Makulatura drukarska z poznańskiego zabytku skłania na koniec do poruszenia kwestii relacji Macieja z Przasnysza i Hieronima Wietora. Czy dowodzi ona jedynie incydentalnego pozyskania przez introligatora papierowych odpadów od drukarza, czy też wskazuje na ich ściślejsze kontakty?

W szczupłych danych dotyczących warsztatu impresora brak informacji o pomocniku introligatorskim. Wzmianka o jego przeprowadzeniu się w 1535 roku do domu przy ul. Gołębiej w Krakowie, w sąsiedztwie siedziby introligatora Stanisława, jest zbyt późna, by wyciągać z niej dalej idące wnioski na temat opraw z lat 20. XVI wieku ${ }^{85}$. Zapewne z późniejszego okresu pochodzi też informacja o ożenku Wietorowskiej córki z drugiego małżeństwa z mieszkającym po sąsiedzku introligatorem Bartłomiejem Gędźcą ${ }^{86}$. Ze skąpych źródeł wiadomo, że już na początku XVI wieku - podczas pierwszego pobytu w Krakowie, a potem w Wiedniu Wietor sam parał się oprawianiem ksiąg87. Brak jednak dowodów na podejmowanie się przez niego takich prac po 1518 roku, odkąd osiadł tu na

${ }^{84}$ Zob. np. J. Grycz, Z dziejów i techniki książki, Wrocław 1951, il. 99; Poolse Boekbindkunst..., kat. 67, 70, il. na s. 55-56; A. Lewicka-Kamińska, Stanisław..., il. 1, 3, 5-6; J. Storm van Leeuwen, op.cit., tabl. na s. 112.

${ }^{85}$ Drukarze dawnej Polski od XV do XVIII wieku, t. 1: Małopolska, cz. 1: Wiek XV-XVI, red. A. Kawecka-Gryczowa, Wrocław 1983, s. 326.

${ }^{86}$ Ibidem.

${ }^{87}$ Ibidem, s. 348-350. Nie odbiegało to od ówczesnej praktyki, reprezentowanej w Koronie przez Melchiora Neringa (zob. np. Z. Mocarski, Książka w Toruniu do roku 1793, Toruń 1934, s. 36; A. Wagner, Oprawy ksiag..., s. 155-161). 
stałe. Do prac introligatorskich odznaczających się silnym pierwiastkiem italianizmu mogła go zbliżyć współpraca z Aldusem Manucjuszem, od którego - wedle przypuszczeń badaczy - już na przełomie XV i XVI wieku sprowadzał do stolicy Królestwa liczne książki ${ }^{88}$. Swej estymie dla humanizmu dawał wyraz publikowaniem m.in. dzieł autorów klasycznych i Erazma z Rotterdamu ${ }^{89}$. Niebagatelne znaczenie mogła mieć też jego wrażliwość na nowe prądy stylowe, owocująca renesansową szatą typograficzną i graficzną wydawnictw, w tym zwłaszcza stosowaniem antykwowego liternictwa ${ }^{90}$. W końcu należy podkreślić żywe kontakty Wietora z Węgrami, skąd sprowadzał księgi ${ }^{91}$. Kraj ten zaś już od czasów króla Macieja Korwina stanowił najwcześniejszy po Italii ośrodek introligatorstwa renesansowego w Europie, co na pewno nie uszło uwadze osobie chłonącej nowinki stylowe.

Okoliczności te mogły przyczynić się do podjęcia aktywniejszej współpracy Wietora z introligatorem gwarantującym nowatorską formę opraw. W działaniach tych mogli dopingować go kościelni i świeccy prominenci, o których względy drukarz zabiegał już w pierwszych latach XVI wieku. W gronie tym wyróżnia się bp Piotr Tomicki, który wspierał drukarskie poczynania Wietora ${ }^{92}$, a zarazem oprawiał swe księgi w pracowni Macieja z Przasnysza ${ }^{93}$. Istnieją zatem przesłanki, by traktować Wietorowską makulaturę w oprawie krakowskiego mistrza jako wyraz ściślejszej współpracy renesansowo zorientowanych twórców. Czy ma to swój wyraz w makulaturze innych dzieł oprawianych przez Macieja z Przasnysza? Pytanie to na razie musi pozostać bez odpowiedzi.

Z podjętej charakterystyki oprawy z poznańskich zbiorów płynie wniosek o jej wysokiej wartości artystycznej i historycznej jako wytworu wybitnego krakowskiego introligatora, Macieja z Przasnysza. W dorobku tego twórcy, określanego w dotychczasowej literaturze jako Mistrz Główek Anielskich, ogniskują się charakterystyczne tendencje krakowskiego introligatorstwa drugiego i trzeciego dziesięciolecia XVI wieku. Polegały

${ }^{88}$ Drukarze dawnej..., s. 348.

${ }^{89}$ Ibidem, s. 328-329, 337-340.

90 Ibidem, s. 328, 343-347.

91 Ibidem, s. 340-341, 349.

92 Ibidem, s. 330, 332, 347, 352.

${ }^{93}$ L. Hajdukiewicz, op.cit. Reprodukcje opraw Macieja z Przasnysza (określanego jako Mistrz Główek Anielskich) z superekslibrisem Tomickiego m.in. w: M. Jarosławiecka-Gąsiorowska, Stan badań i próba dziejów oprawy artystycznej w Polsce, „Prace Komisji Historii Sztuki" 1948, t. 9, il. 43; J. Samek, Rzemiosło artystyczne w Polsce, Warszawa 1971, tabl. 137-138; Oprawy polskie..., tabl. 3; Poolse Boekbindkunst..., il. na s. 61. 
one na wyraźnym italianizmie kompozycji dekoracji, doboru narzędzi zdobniczych, a nawet niektórych materiałów i struktury oprawy. Omówione dzieło wykazuje bliskie związki formalne $\mathrm{z}$ jedną $\mathrm{z}$ odmian dekoracji, tzw. opraw aldyńskich, która w pierwszej ćwierci XVI wieku zyskała popularność w Wenecji i innych ośrodkach włoskiego introligatorstwa. Jej charakterystyczną cechą był motyw linearnej ramki z półkolistymi wybrzuszeniami (półpierścieniami) na osiach, które wzbogacały nieliczne wyciski motywów floralnych. Fakt wykonania oprawy w 1526 roku przesądza o jej zaliczeniu do wczesnych przykładów zastosowania tego wzorca w skali europejskiej. Na tle introligatorstwa polskiego okazuje się dziełem awangardowym, wyprzedzającym podobne - zwłaszcza krakowskie - oprawy o kilkanaście lat. Z powyższymi cechami współistnieje wysoki poziom wykonawczy dzieła, objawiający się głównie starannością w rozdysponowaniu i wyciśnięciu poszczególnych składników dekoracji. Szczególnej wartości dodaje jej również makulatura drukarska, dowodząca współpracy Macieja z Przasnysza z czołowym reprezentantem renesansu w drukarstwie krakowskim, Hieronimem Wietorem.

Okoliczności te stawiają poznański zabytek, wespół z całym dorobkiem Macieja z Przasnysza, w rzędzie czołowych przejawów italianizmu $\mathrm{w}$ introligatorstwie polskim i europejskim pierwszej połowy XVI wieku.

\title{
On the unknown binding of a book from Jan Laski book collection currently held at Poznań University Library. A contribution to the study on the Italian influences in Polish bookbinding of the sixteenth century
}

\begin{abstract}
Aвstract. The present article begins with an analysis of a binding from the book collection of Jan Łaski (1499-1560) that has been recently discovered. The description aims to focus on characteristic elements indicating the Italian influence in the ornamentation of the covers. The characteristic features of the work are compared against the background of Italian Renaissance bookbinding traditions, in particular with that of the bookbinding workmanship distinguishing and representative of the group of
\end{abstract}


bookbinders from Venice. A particular attention is given to the superexlibris stamped on the front cover with its form copying the characteristic type of the Italian shield of testa di cavallo form. The author then proceeds to discuss the issue of the place of manufacture of the binding and its authorship. The provided comparative analysis with other Italian-influenced bindings manufactured in Cracow in the 1520s shows that its authorship can be attributed to Maciej of Przasnysz, defined in literature as the Master of Cherub Heads. Advanced Renaissance forms in the works of this bookbinder, including the bindings from the Poznan collection, may prove him to be one of the leading European book artisans, who was capable of immediate absorbing the most recent and contemporary trends in bookbinding in Italy.

Key words: Jan Łaski, Joannes a Lasco, Maciej of Przasnysz, Master of Cherub Heads, Renaissance bookbinding, Italianism (Italian influences), bookbinding, superexlibris. 
